\title{
Methane and nitrous oxide exchange over a managed hay meadow
}

\author{
L. Hörtnagl ${ }^{1, *}$ and G. Wohlfahrt ${ }^{1,2}$ \\ ${ }^{1}$ Institute of Ecology, University of Innsbruck, Austria \\ ${ }^{2}$ European Academy of Bolzano, Bolzano, Italy \\ *now at: Department of Environmental Systems Science, Institute of Agricultural Sciences IAS, ETH Zurich, Switzerland
}

Correspondence to: L. Hörtnagl (lukas.hoertnagl@usys.ethz.ch)

Received: 29 April 2014 - Published in Biogeosciences Discuss.: 5 June 2014

Revised: 13 October 2014 - Accepted: 6 November 2014 - Published: 17 December 2014

\begin{abstract}
The methane $\left(\mathrm{CH}_{4}\right)$ and nitrous oxide $\left(\mathrm{N}_{2} \mathrm{O}\right)$ exchange of a temperate mountain grassland near Neustift, Austria, was measured during 2010-2012 over a time period of 22 months using the eddy covariance method. Exchange rates of both compounds at the site were low, with $97 \%$ of all half-hourly $\mathrm{CH}_{4}$ and $\mathrm{N}_{2} \mathrm{O}$ fluxes ranging between \pm 200 and $\pm 50 \mathrm{ng} \mathrm{m}^{-2} \mathrm{~s}^{-1}$, respectively. The meadow acted as a sink for both compounds during certain time periods, but was a clear source of $\mathrm{CH}_{4}$ and $\mathrm{N}_{2} \mathrm{O}$ on an annual timescale. Therefore, both gases contributed to an increase of the global warming potential (GWP), effectively reducing the sink strength in terms of $\mathrm{CO}_{2}$ equivalents of the investigated grassland site. In 2011, our best guess estimate showed a net greenhouse gas (GHG) sink of $-32 \mathrm{~g} \mathrm{CO}_{2}$ equ. $\mathrm{m}^{-2} \mathrm{yr}^{-1}$ for the meadow, whereby $55 \%$ of the $\mathrm{CO}_{2}$ sink strength of $-71 \mathrm{~g} \mathrm{CO}_{2} \mathrm{~m}^{-2} \mathrm{yr}^{-1}$ was offset by $\mathrm{CH}_{4}\left(\mathrm{~N}_{2} \mathrm{O}\right)$ emissions of 7 (32) $\mathrm{g} \mathrm{CO}_{2}$ equ. $\mathrm{m}^{-2} \mathrm{yr}^{-1}$. When all data were pooled, the ancillary parameters explained 27 (42)\% of observed $\mathrm{CH}_{4}\left(\mathrm{~N}_{2} \mathrm{O}\right)$ flux variability, and up to $62(76) \%$ on shorter timescales in-between management dates. In the case of $\mathrm{N}_{2} \mathrm{O}$ fluxes, we found the highest emissions at intermediate soil water contents and at soil temperatures close to 0 or above $14{ }^{\circ} \mathrm{C}$.

In comparison to $\mathrm{CO}_{2}, \mathrm{H}_{2} \mathrm{O}$ and energy fluxes, the interpretation of $\mathrm{CH}_{4}$ and $\mathrm{N}_{2} \mathrm{O}$ exchange was challenging due to footprint heterogeneity regarding their sources and sinks, uncertainties regarding post-processing and quality control. Our results emphasize that $\mathrm{CH}_{4}$ and $\mathrm{N}_{2} \mathrm{O}$ fluxes over supposedly well-aerated and moderately fertilized soils cannot be neglected when evaluating the GHG impact of temperate managed grasslands.
\end{abstract}

\section{Introduction}

Methane $\left(\mathrm{CH}_{4}\right)$ and nitrous oxide $\left(\mathrm{N}_{2} \mathrm{O}\right)$ are the most important anthropogenic greenhouse gases (GHGs) after carbon dioxide $\left(\mathrm{CO}_{2}\right)$. Due to their long atmospheric lifetimes of approx. 9 and 131 years (Prather et al., 2012), respectively, both compounds are well mixed in the atmosphere and can influence atmospheric chemistry directly and indirectly. The emission or deposition strength of terrestrial ecosystems is possibly influenced by climate change, which may trigger important feedbacks to the global climate system (Xu-Ri et al., 2012).

$\mathrm{CH}_{4}$ has a major influence on the climate and chemistry of the atmosphere (Crutzen and Lelieveld, 2001; Khalil et al., 2007). $\mathrm{CH}_{4}$ can react with hydroxyl radicals, resulting in a reduction of the oxidizing capacity of the atmosphere and the production of ozone $\left(\mathrm{O}_{3}\right)$ in the troposphere. Methane can influence the lifetime or production of other atmospheric constituents such as stratospheric water vapor and $\mathrm{CO}_{2}$ (Boucher et al., 2009; Collins et al., 2010; Shindell et al., 2009). Its global warming potential over a 100-year lifespan(GWP) and on a per molecule basis is 25 times that of $\mathrm{CO}_{2}$ (Forster et al., 2007) or higher when the production of $\mathrm{CO}_{2}$ from $\mathrm{CH}_{4}$ oxidation is taken into account (Boucher et al., 2009).

The main portion of global $\mathrm{CH}_{4}$ originates from singlecelled archaea (methanogens) found in anaerobic microsites in the soil, in water-saturated zones rich in carbon and in the digestive systems of ruminants (Baldocchi et al., 2012; Whalen, 2005). $\mathrm{CH}_{4}$ is also emitted from organic waste deposits, e.g. manure or from thermogenic and pyrogenic sources (Kirschke et al., 2013). The highest emissions were previously reported from regions with intensive agriculture and animal husbandry (Schulze et al., 2009). Atmospheric 
$\mathrm{CH}_{4}$ increased significantly since the industrial revolution until the end of the 1990s, remained constant for nearly a decade and again began to increase after 2007 (Bousquet et al., 2011; Dlugokencky et al., 2009; Nisbet et al., 2014).

The main sink of methane is through its reaction with the hydroxyl radical $\mathrm{OH}$ in the troposphere (Ehhalt and Heidt, 1973). Other minor sinks are methanotrophic bacteria in aerated soils and reactions with atmospheric constituents in the stratosphere and the marine boundary layer (Allan et al., 2007; Cicerone and Oremland, 1988). Previous studies reported reduced $\mathrm{CH}_{4}$ deposition in a forest and in a temperate grassland due to elevated $\mathrm{CO}_{2}$ (Dubbs and Whalen, 2010; Ineson et al., 1998; Phillips et al., 2001) and increased $\mathrm{CH}_{4}$ uptake due to warming in a temperate forest and several subarctic ecosystems (Peterjohn et al., 1994; Sjogersten and Wookey, 2002).

$\mathrm{N}_{2} \mathrm{O}$ can deplete $\mathrm{O}_{3}$ in the upper regions and increase $\mathrm{O}_{3}$ in the lower regions of the stratosphere (Revell et al., 2012). It can therefore influence tropospheric chemistry by increasing the stratosphere-troposphere exchange of $\mathrm{O}_{3}$ and odd nitrogen species, and by increasing $\mathrm{OH}$ formation (Prather and Hsu, 2010). Similar to $\mathrm{CH}_{4}, \mathrm{~N}_{2} \mathrm{O}$ has a high warming potential, 298 times that of $\mathrm{CO}_{2}$ over a 100-year lifespan (Forster et al., 2007). The dominant source of $\mathrm{N}_{2} \mathrm{O}$ is microbial production through nitrification and denitrification processes in soils, which is fueled by accelerated use of nitrogen fertilizers in agriculture (Davidson, 2009; Fowler et al., 2009). As a consequence of fertilization, agricultural soils are unlikely to act as a sink for $\mathrm{N}_{2} \mathrm{O}$ (Syakila and Kroeze, 2011).

The production of $\mathrm{N}_{2} \mathrm{O}$ by bacteria in soils is controlled by a number of factors, for example, soil water content, temperature and labile carbon availability (Barnard et al., 2005; Holtan-Hartwig et al., 2002; Xu-Ri and Prentice, 2008). Food production was described as the largest single source of $\mathrm{N}_{2} \mathrm{O}$ (Syakila and Kroeze, 2011), while photolysis and oxidation reactions in the stratosphere are the main processes involved in $\mathrm{N}_{2} \mathrm{O}$ depletion (Prather et al., 2012).

Denitrification is an anaerobic process (Zumft and Kroneck, 2007) that is likely exclusively responsible for $\mathrm{N}_{2} \mathrm{O}$ uptake in the soil (Vieten et al., 2008). On a global scale, the uptake of $\mathrm{N}_{2} \mathrm{O}$ by soils may be limited (Chapuis-Lardy et al., 2007). Schlesinger (2013) estimated that the global $\mathrm{N}_{2} \mathrm{O}$ sink in soils is not more than $2 \%$ of current estimated sources in the atmosphere. Deposition fluxes to the soil were reported before, e.g., for grasslands, forests, low-nitrogen soils, wetlands and peatlands (Dijkstra et al., 2013; Flechard et al., 2005; Goldberg and Gebauer, 2009a, b; Schlesinger, 2013; Syakila et al., 2010; Wu et al., 2013).

Over managed grasslands, $\mathrm{CH}_{4}$ and $\mathrm{N}_{2} \mathrm{O}$ fluxes are characterized by high spatial and temporal variability (Baldocchi et al., 2012; Imer et al., 2013), with emissions of both compounds greatly influenced by land use, management events and animal husbandry. As a consequence, long-term yearround GHG measurements are indispensable when it comes to assessing the effectiveness and feasibility of GHG mitigation strategies.

In this work we present long-term eddy covariance $\mathrm{CH}_{4}$ and $\mathrm{N}_{2} \mathrm{O}$ fluxes above a temperate mountain grassland near Neustift, Austria. To this end we investigated 22 months of diurnal, seasonal and interannual exchange rates of both compounds at ecosystem scale and in relation to biotic and abiotic drivers under in situ conditions.

The objective of this study is to (1) quantify eddy covariance $\mathrm{CH}_{4}$ and $\mathrm{N}_{2} \mathrm{O}$ fluxes, (2) couple exchange patterns to independent driving variables, (3) determine the annual total GHG balance and (4) compare our findings to previous results from chamber and eddy covariance measurements at ecosystem scale and from laboratory measurements. In-line with these objectives and based on earlier studies, we hypothesized for both compounds that (1) the investigated grassland, due to generally well-aerated soils and modest fertilizer input, is characterized by low fluxes and (2) exchange patterns are predominantly driven by soil parameters. In addition we assumed that (3) despite their low fluxes, $\mathrm{CH}_{4}$ and $\mathrm{N}_{2} \mathrm{O}$ exchange significantly contribute to the GHG balance of the meadow.

The study site Neustift, a managed temperate mountain grassland in Austria that is cut three times per year for hay production, was selected because it has been the focus of numerous studies over the last 10 years and is therefore well described in terms of management effects, net ecosystem $\mathrm{CO}_{2}, \mathrm{H}_{2} \mathrm{O}$, energy (Brilli et al., 2011; Hammerle et al., 2008; Wohlfahrt et al., 2008b) and volatile organic compound (VOC) exchange (Bamberger et al., 2010, 2011; Brilli et al., 2012; Hörtnagl et al., 2011, 2014; Müller et al., 2010; Ruuskanen et al., 2011).

\section{Methods}

\subsection{Site description}

The study site is an intensively managed meadow in the middle of the flat valley bottom of the Stubai valley in the Austrian Alps, in proximity of the village of Neustift $\left(47^{\circ} 70^{\prime} \mathrm{N}, 11^{\circ} 19^{\prime} \mathrm{E}\right)$ at an elevation of $970 \mathrm{~m}$ a.s.l. The climate is humid continental with alpine influences, with an average annual temperature of $6.5^{\circ} \mathrm{C}$; the average annual precipitation amounts to $852 \mathrm{~mm}$. The fetch is homogeneous up to $300 \mathrm{~m}$ to the north-northeast (the dominant daytime wind direction) and $900 \mathrm{~m}$ to the south-southwest (nighttime) of the instrument tower, parallel to the valley's orientation. Typically, higher wind speeds and unstable conditions result in a smaller footprint during daytime than during nighttime, where the footprint of the site is larger due to the stable stratification of the atmosphere (Bamberger et al., 2010). The vegetation of the meadow is dominated by a few graminoids (Dactylis glomerata, Festuca pratensis, Phleum pratensis, Trisetum flavescens) and forbs (Ranunculus acris, 

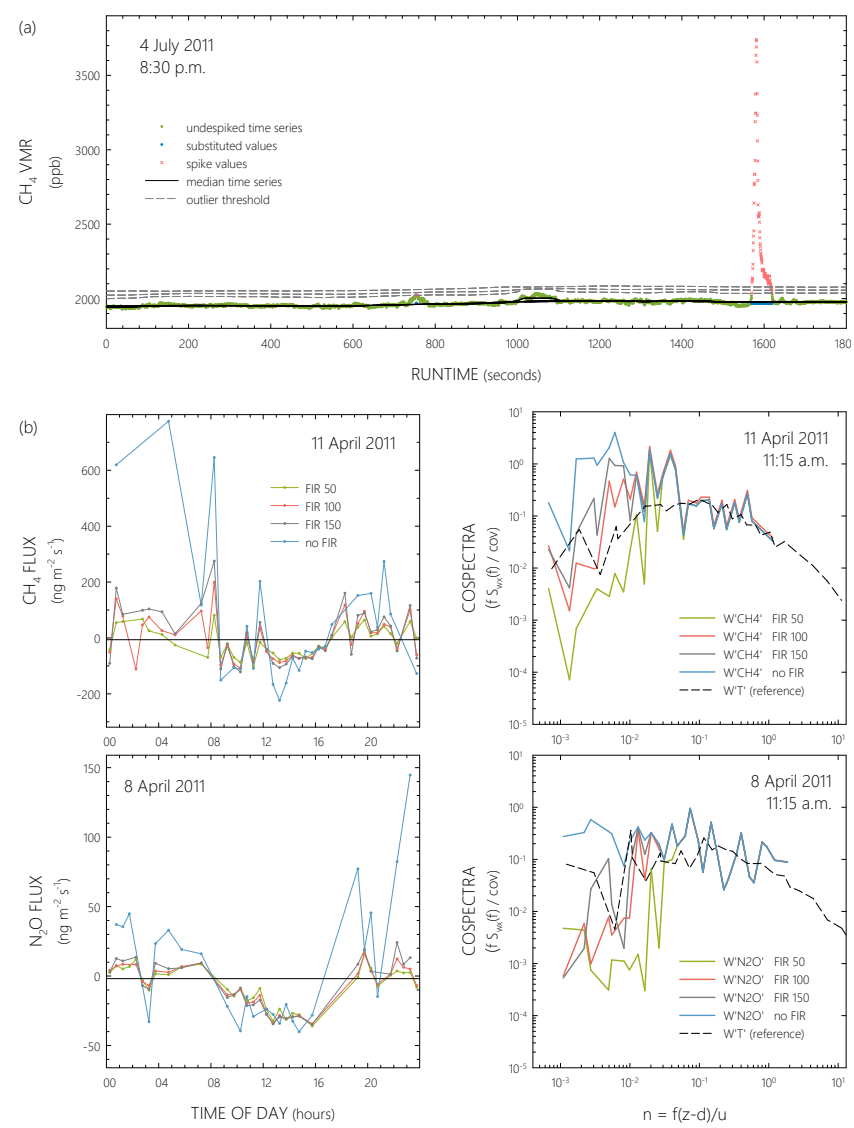

Figure 1. (a) Despiking example of $2 \mathrm{~Hz}$ methane volume mixing ratios (VMRs) using median filters. (b) Diurnal courses (left panels) and normalized co-spectra (right panels) illustrating the effect of high-pass filtering $\mathrm{CH}_{4}$ (upper panels) and $\mathrm{N}_{2} \mathrm{O}$ (lower panels) time series with a non-recursive finite impulse response (FIR) filter with different time constants $(50,100$ and $150 \mathrm{~s})$. Sensible heat co-spectra are shown in the right panels for reference.

Taraxacum officinale, Trifolium repens, Trifolium pratense, Carum carvi), while the slopes of the surrounding mountains are covered mainly by coniferous forest. The soil was classified as a Fluvisol (FAO classification) and is approx. $1 \mathrm{~m}$ deep, with a thin organic layer $(0.001 \mathrm{~m})$, followed by an A horizon that extends down to $0.02 \mathrm{~m}$ and a B horizon, best described as a sandy loam. The organic volume fraction of the A horizon is approx. $14 \%$.

Measurements of $\mathrm{CH}_{4}$ and $\mathrm{N}_{2} \mathrm{O}$ for this work were conducted from 13 April 2010 to 29 February 2012 (684 days). In each year, the meadow was cut three times, with the first cut on 5 and 6 June, the second cut on 31 July and 1 August and the third cut on 20 and 26 September in 2010 and 2011, respectively. In addition, the meadow was fertilized by manure spreading between 18-22 October in 2010 and on 1819 October in 2011. The meadow was snow covered from 1 January to 28 February 2010, from 26 November 2010 to 10 March 2011 and from 7 December 2011 to 24 March 2012, resulting in a total of 246 snow days for this analysis. During the measurement campaign, no cows were present on the meadow.

\subsection{Eddy covariance measurements}

The net ecosystem exchange for $\mathrm{CH}_{4}$ and $\mathrm{N}_{2} \mathrm{O}$ was calculated by combining the $20 \mathrm{~Hz}$ three-dimensional wind speeds quantified by a sonic anemometer (R3IA, Gill Instruments, Lymington, UK) at a height of $2.5 \mathrm{~m}$ above ground with the simultaneously detected volume mixing ratios (VMRs) of $\mathrm{CH}_{4}$ and $\mathrm{N}_{2} \mathrm{O}$, which were both measured by a commercially available continuous-wave quantum cascade laser (QCL; CWQC-TILDAS-76-D, Aerodyne, USA). Fluxes were then calculated using the virtual disjunct eddy covariance (vDEC) method proposed by Karl et al. (2002), which is based on the eddy covariance (EC) method (Baldocchi et al., 1988; McMillen, 1988). The intake tube for the QCL was mounted at $0.2 \mathrm{~m}$ below the sonic anemometer and displaced laterally perpendicular to the predominating wind direction in order to minimize flux loss due to vertical and longitudinal sensor separation (Massman, 2000). Sample air was drawn from the inlet through a filter $(1-2 \mu \mathrm{m}$, polytetrafluoroethylene, PTFE) and heated $\left(35^{\circ} \mathrm{C}\right)$ perfluoroalkoxy (PFA) Teflon ${ }^{\circledR}$ tubing $\left(1 / 4^{\prime \prime}\right.$ inner diameter) of $12 \mathrm{~m}$ length to the QCL at a flow rate of around 8SLPM (standard liter per minute; air volume normalized to standard temperature and pressure conditions: $273 \mathrm{~K}, 1013 \mathrm{hPa}$ ). Sonic anemometer data were stored to the hard drive of a personal computer using the Eddymeas software (O. Kolle, Max Planck Institute for Biogeochemistry, Jena, Germany). More details regarding the $\mathrm{CO}_{2}$, $\mathrm{H}_{2} \mathrm{O}$ and energy flux measurements are given in Wohlfahrt et al. (2008) and Hammerle et al. (2008).

\subsection{QCL setup}

Ambient air was analyzed for $\mathrm{CH}_{4}, \mathrm{~N}_{2} \mathrm{O}$ and $\mathrm{H}_{2} \mathrm{O}$ at time resolutions of $10 \mathrm{~Hz}$ (13 March-16 August 2010), $5 \mathrm{~Hz}$ (1624 August 2010) and $2 \mathrm{~Hz}$ (26 August 2010-29 February 2012). The QCL and associated hardware (vacuum pump and Thermo Cube ${ }^{\circledR}$ ) were housed in a climate-controlled instrument hut next to the field site. During the last $5 \mathrm{~min}$ of every half hour, $\mathrm{CH}_{4}$-free and $\mathrm{N}_{2} \mathrm{O}$-free air and air with known, close-to-ambient VMRs were switched into the sampling line to determine zero and span of the QCL, respectively. The QCL was operated at a pressure of $4 \mathrm{kPa}$ using a built-in pressure controller and temperature of the optical bench and housing controlled to $35^{\circ} \mathrm{C}$. The importance of a temperature controlled environment was previously pointed out by Kroon et al. (2007). Fitting of absorption spectra, storing of calculated VMRs, switching of zero-calibration valves, control of pressure lock and other system controls were realized by the TDLWintel software (Aerodyne, USA) run on a personal computer synchronized with the main personal 
computercollecting anemometer data using the NTP software (Meinberg, Germany).

\subsection{Despiking}

Similar to observations by Baldocchi et al. (2012) for methane, we experienced elevated VMRs of both compounds, but especially $\mathrm{CH}_{4}$, at night. We attributed these increased VMRs to atmospheric phenomena in the calm and stable nocturnal boundary layer rather than to elevated biogenic emissions. Therefore, VMRs of both compounds were subjected to a rigorous outlier removal routine before entering flux calculations (Fig. 1a). The despiking method in this study is based on a median filter that runs through each halfhourly VMR time series data point by data point. In comparison to the arithmetic mean, the median value of a time series is relatively insensitive to outlier values. For each half-hourly period, (1) a smoothed time series of the original VMR time series was created. This was done by replacing each original data point with the median value of a moving time window of \pm 500 values around the respective VMR value. In order to enable the calculation of median values also for data points at the start and end of the measured time series, the first and last 500 values were copied and repeated at the start and end of the smoothed time series, respectively. (2) Each data point in the smoothed time series was then subtracted from the respective measured data point, generating a time series of differences between the two data matrices. (3) When the difference exceeded the empirically determined outlier threshold of $100 \mathrm{ppb}$, the data point in the measured time series was marked as an outlier. This outlier threshold was tailored to the $\mathrm{CH}_{4}$ variability, but also worked well for removing extreme values in the $\mathrm{N}_{2} \mathrm{O}$ time series. (4) The arithmetic mean without these outliers was then calculated and used to (5) replace outliers in the respective half-hourly time series. As turbulent fluctuations for final flux computations are calculated using block averaging, the contribution of these substituted data points to resulting half-hourly fluxes is minor. To better account for natural variability in the time series, three different runs with varying window sizes ( $\pm 500,250,150$ values) and outlier thresholds $(100,80,60 \mathrm{ppb})$ were performed for each half-hourly period.

During daytime and nighttime, at least one outlier was removed in 30 and $66 \%$ of half-hourly $\mathrm{CH}_{4}$, but only in 1 and $1 \%$ of all recorded $\mathrm{N}_{2} \mathrm{O}$ VMRs, respectively.

\subsection{Flux calculations}

Half-hourly fluxes of $\mathrm{CH}_{4}\left(F_{\mathrm{CH}_{4}}\right)$ and $\mathrm{N}_{2} \mathrm{O}\left(F_{\mathrm{N}_{2} \mathrm{O}}\right)$ were then calculated using the virtual disjunct eddy covariance (vDEC) method (Karl et al., 2002) as the covariance between turbulent fluctuations of the vertical wind speed and the VMRs derived from Reynolds averaging of 30 min blocks of data. The time lag between the high-resolution wind data and the disjunct QCL time series was removed using a homemade program, resulting in a subsample of the wind data corresponding to the sampling rate of the QCL. In the same step, $\mathrm{CH}_{4}$ and $\mathrm{N}_{2} \mathrm{O}$ fluxes were corrected for the effect of air density fluctuations and laser band broadening following Neftel et al. (2010), using the QCL $\mathrm{H}_{2} \mathrm{O}$ VMR. It was shown previously that flux estimates using the vDEC method are characterized by a larger random uncertainty compared to the true EC, but are unbiased (Hörtnagl et al., 2010). The tubing induced delay time between the wind and the QCL concentration time series was determined in a procedure comprising multiple steps. First, the correlation coefficient between the $\mathrm{H}_{2} \mathrm{O}$ time series measured concurrently by the QCL and a closed-path infrared gas analyzer (Li-7000, LiCor, USA), the data of which were acquired together with the sonic anemometer wind data, was optimized to remove potential time differences between the two personal computers caused by deviating internal clocks, effectively adjusting the starting points of the two time series. Due to generally low values of $F_{\mathrm{CH}_{4}}$ and $F_{\mathrm{N}_{2} \mathrm{O}}$ at our study site, the determination of lag times between the $\mathrm{CH}_{4}$ or $\mathrm{N}_{2} \mathrm{O}$ time series and the wind data was difficult, but worked well between the QCL $\mathrm{H}_{2} \mathrm{O}$ signal and the wind data. Therefore, second, the time delay between the wind components and the QCL $\mathrm{H}_{2} \mathrm{O}$ was determined by identifying the maximum/minimum of the cross-correlation function in a time window of $\pm 7 \mathrm{~s}$. The frequency distribution of this search revealed a peak around $2 \mathrm{~s}$. Third, a second time window of $\pm 2 \mathrm{~s}$ (daytime) and $\pm 5 \mathrm{~s}$ (nighttime) was then applied around this peak and used for the final lag search between the $\mathrm{CH}_{4}$ or $\mathrm{N}_{2} \mathrm{O}$ signal and the vertical wind velocity.

Final fluxes were then calculated using the post-processing software EdiRe (University of Edinburgh). Frequency response corrections were applied to raw fluxes of both compounds, accounting for high-pass (block averaging, finite impulse response filter) and low-pass (lateral sensor separation, dynamic frequency response, scalar and vector path averaging, frequency response mismatch and the attenuation of concentration fluctuations down the sampling tube) filtering according to Massman (2000), using a site-specific co-spectral reference model (Wohlfahrt et al., 2005a). The importance of correcting $\mathrm{CH}_{4}$ and $\mathrm{N}_{2} \mathrm{O}$ fluxes for highfrequency losses was shown previously (Kroon et al., 2010c). The high-pass, non-recursive finite impulse response (FIR) filter was applied digitally to account for an overestimation of the flux contributions of low-frequency eddies. The best results were achieved by applying the FIR filter using a Hamming window, whereby time constants of 50 and $100 \mathrm{~s}$ for $\mathrm{CH}_{4}$ and $\mathrm{N}_{2} \mathrm{O}$, respectively, sufficiently filtered out unwanted flux contributions at frequencies $<0.05 \mathrm{~Hz}$ (Fig. 1b). Missing low-frequencies were then back-corrected based on the site-specific reference model co-spectrum (Wohlfahrt et al., 2005b). Exchange rates of $\mathrm{CH}_{4}$ and $\mathrm{N}_{2} \mathrm{O}$ calculated with these settings represent our final best guess fluxes that were used for all analyses in this manuscript. 
Two days in April 2011 are used to exemplify the effect of different FIR filters, applied to the $\mathrm{CH}_{4}$ and $\mathrm{N}_{2} \mathrm{O}$ time series, on the resulting flux estimates (Fig. 1b). The largest difference between unfiltered and filtered data, as well as between the different filter time constants, was found during nighttime. In contrast, during turbulent conditions, e.g., around noon, fluxes calculated with different time constants exhibited exchange patterns of comparable magnitude (Fig. 1b, left panels). FIR filtering had a larger effect on $\mathrm{CH}_{4}$ than on $\mathrm{N}_{2} \mathrm{O}$ fluxes. As an example, over the course of one day unfiltered $\mathrm{CH}_{4}$ exchange rates fluctuated between -217 and $780 \mathrm{ng} \mathrm{m}^{-2} \mathrm{~s}^{-1}$ (average: $4 \pm 260 \mathrm{ng} \mathrm{m}^{-2} \mathrm{~s}^{-1}$ ), while best guess fluxes ranged between -96 and $87 \mathrm{ng} \mathrm{m}^{-2} \mathrm{~s}^{-1}$ after FIR filtering $(-7 \pm 51)$. Similarly, unfiltered $\mathrm{N}_{2} \mathrm{O}$ fluxes were between -38 and $146 \mathrm{ng} \mathrm{m}^{-2} \mathrm{~s}^{-1}(11 \pm 46)$, with best guess fluxes between -33 and $18 \mathrm{ng} \mathrm{m}^{-2} \mathrm{~s}^{-1}(-5 \pm 15)$. Cospectral analyses revealed that lower frequencies of the $\mathrm{CH}_{4}$ and $\mathrm{N}_{2} \mathrm{O}$ fluxes were overrepresented compared to the sensible heat flux (Fig. 1b, right panels).

In total, 28891 raw flux values were calculated for $\mathrm{CH}_{4}$ and $\mathrm{N}_{2} \mathrm{O}$, which corresponds to a data coverage of $88 \%$ over the whole measurement period between 13 March 2010 and 29 February 2012. Flux results of each FIR run required separate quality control. When applying a FIR filter with a time constant of $50 / 100 / 150 \mathrm{~s}$ to the data, $57 / 55 / 55 \%$ of all raw $\mathrm{CH}_{4}$ fluxes and $66 / 64 / 63 \%$ of all raw $\mathrm{N}_{2} \mathrm{O}$ fluxes passed all quality tests, respectively. However, only 28 and $39 \%$ of all raw $\mathrm{CH}_{4}$ and $\mathrm{N}_{2} \mathrm{O}$ fluxes, respectively, passed all tests when no FIR filter was used in the flux calculations. Only data that passed all quality tests in a respective scenario were used in the present study. All fluxes in this manuscript are expressed as molecular mass per unit time and ground surface area.

In order to calculate the annual balance of $\mathrm{CH}_{4}$ and $\mathrm{N}_{2} \mathrm{O}$ in 2011, the respective quality-controlled half-hourly flux data set was gap-filled. Gaps less than or equal to $2 \mathrm{~h}$ were filled by linear interpolation. For the filling of larger gaps a lookup table was generated, using flux data in a time window of 14 days around the missing flux value and $T_{\text {soil }}$ bin widths of $1^{\circ} \mathrm{C}$. If no lookup table could be generated, e.g. no flux data were available within the time window, the mean diurnal variation ( \pm 14 days) was used to fill the gap. For the calculation of the annual GWP of the meadow in Neustift, $\mathrm{CH}_{4}$ and $\mathrm{N}_{2} \mathrm{O}$ fluxes were converted to $\mathrm{CO}_{2}$ equivalents using the respective compound warming potential as given by Forster et al. (2007).

Instrumentation, data treatment, quality control of $\mathrm{CO}_{2}$ and sensible and latent heat fluxes have been described at length by Wohlfahrt et al. (2008) and Hammerle et al. (2008).

\subsection{Quality control}

Half-hourly methane and nitrous oxide fluxes were excluded from the analysis if (i) the deviation of the integral similarity characteristics was larger than $60 \%$ (Fo- ken and Wichura, 1996), (ii) the maximum of the footprint function (Hsieh et al., 2000) was outside the boundaries of the meadow, (iii) fluxes were outside a specific range $\left(F_{\mathrm{CH}_{4}}: \pm 800 \mathrm{ng} \mathrm{m}^{-2} \mathrm{~s}^{-1}, F_{\mathrm{N}_{2} \mathrm{O}}: \pm 220\right)$, (iv) halfhourly VMRs were outside a specific range $\left(\mathrm{CH}_{4}: 1800\right.$ $3500 \mathrm{ppb}, \mathrm{N}_{2} \mathrm{O}: 280-450 \mathrm{ppb}$ ), (v) the stationarity test for the respective flux exceeded $60 \%$ (Foken and Wichura, 1996), (vi) the third rotation angle exceeded $10^{\circ}$ (McMillen, 1988), (vii) the number of half-hourly VMR values was below 3000 or (viii) more than $20 \%$ of data were classified as spikes in any half-hourly period.

\subsection{Ancillary data}

Major environmental parameters were measured continuously at the field site, including air temperature $\left(T_{\text {air }}\right)$, soil temperature $\left(T_{\text {soil }}\right)$ at $0.05 \mathrm{~m}$ depth (TCAV thermocouple, Campbell Scientific, Logan, UT, USA), volumetric soil water content (SWC) (ML2x, Delta-T Devices, Cambridge, UK), soil heat flux (SHF) quantified by means of heat flux plates (three replicates at $0.05 \mathrm{~m}$ depth, corrected for the change in heat storage above that depth; HFP01, Hukseflux, Delft, the Netherlands), total photosynthetically active radiation (PAR) (BF3H, Delta-T, Cambridge, UK) and precipitation (52202, R. M. Young, Traverse City, MI, USA). All data were collected continuously by a data logger (CR10X, Campbell Scientific, Logan, UT, USA). The green plant area index (GAI) was assessed (i) in a destructive fashion by harvesting the plant matter of square plots $\left(0.09 \mathrm{~m}^{2}, 3-5\right.$ replicates) and subsequent plant area determination (Li-3100, LiCor, Lincoln, NE, USA) and (ii) from measurements of canopy height which were related to destructively measured GAI (Wohlfahrt et al., 2008b). Continuous time series of the GAI were derived by fitting appropriate empirical functions to measured data separately for each growing phase before and after cutting events. A more detailed list of all auxiliary parameters measured at this site is given by Wohlfahrt et al. (2008b) and Hammerle et al. (2008).

\subsection{Statistical analyses}

Statistical analyses were done using Statistica 9 (StatSoft, Inc.), SigmaPlot 12.5 (Systat Software, Inc.) and Excel 2010 (Microsoft, Inc.). The natural logarithm (ln) of the observed daily average $\mathrm{CH}_{4}$ and $\mathrm{N}_{2} \mathrm{O}$ fluxes was calculated and used in the simple linear regression (SLR) and multiple linear regression (MLR) analyses as the dependent variable. The partial correlation in the MLR analysis gives the correlation between two variables after controlling for the effect of all other variables in the equation. To determine significant differences between daily average group means in a repeated measures analysis of variance (ANOVA) setting, the unequal n HSD (honest significant difference) post hoc test, a modification of the Tukey's HSD test, was used. For statistical analyses, only days or half hours where all parameters were 


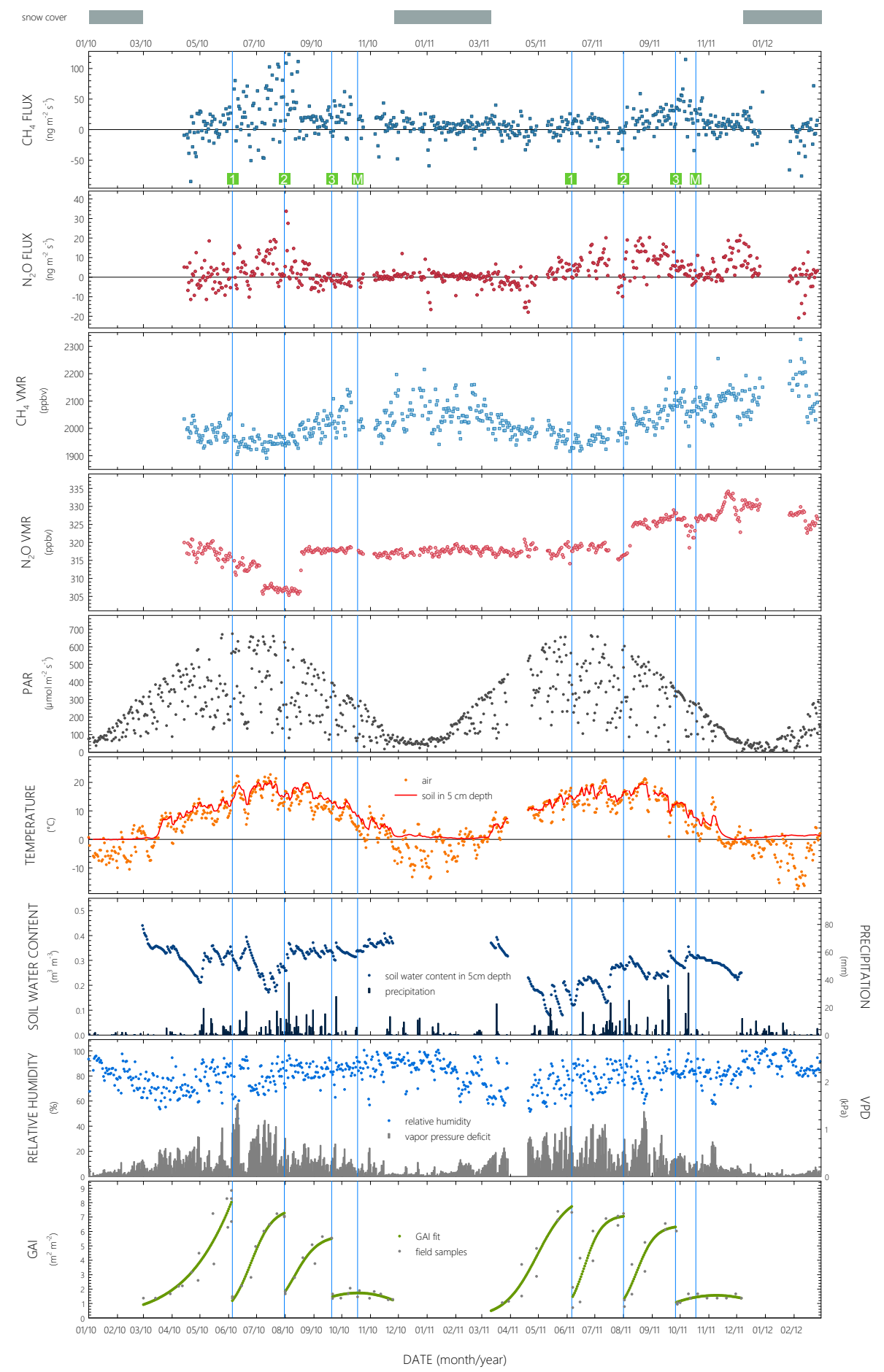

Figure 2. Daily average $\mathrm{CH}_{4}$ and $\mathrm{N}_{2} \mathrm{O}$ fluxes and volume mixing ratios (VMRs), photosynthetically active radiation (PAR), air temperature, soil temperature at $5 \mathrm{~cm}$ depth, soil water content at $5 \mathrm{~cm}$ depth, relative air humidity, vapor pressure deficit, green plant area index (GAI) and daily sums of precipitation over 22 months of measurements between April 2010 and February 2012. Vertical lines show management dates, the numbers 1, 2 and 3 in green squares indicate the first, second and third cutting of the meadow, respectively, while $M$ denotes manure spreading. 
available were included. In case of ancillary data, the daily average of the respective parameter was calculated when at least 40 half hours of data were present for the respective day. In comparison, fewer values were available for $\mathrm{CH}_{4}$ and $\mathrm{N}_{2} \mathrm{O}$ fluxes and VMRs due to the strict quality criteria. For $\mathrm{CH}_{4}$ and $\mathrm{N}_{2} \mathrm{O}$ data, the daily average was regarded as representative for the day when at least 14 half hours were available after quality control. In total 91 and $95 \%$ of the presented $\mathrm{CH}_{4}$ and $\mathrm{N}_{2} \mathrm{O}$ daily average values, respectively, were calculated from at least 20 half-hourly values. Using daily average values of $\mathrm{CH}_{4}$ and $\mathrm{N}_{2} \mathrm{O}$ fluxes in the statistical analyses as opposed to $30 \mathrm{~min}$ flux averages reduces random uncertainty (Kroon et al., 2010a).

\section{Results}

Daily average values of $F_{\mathrm{CH}_{4}}\left(F_{\mathrm{N}_{2} \mathrm{O}}\right)$ were calculated for 567 (574) out of 684 days (Fig. 2). While fluxes of both compounds fluctuated around zero towards the end of the vegetation period and during snow cover, net emission and deposition on a daily basis occurred for both compounds during certain time periods. Daily net uptake (negative sign) was recorded on 162 (203) days, whereby time periods characterized by clear deposition were found especially for $\mathrm{N}_{2} \mathrm{O}$, for example some weeks after snowmelt in spring 2011 (Fig. 2). Highest daily average emissions for $\mathrm{CH}_{4}\left(\mathrm{~N}_{2} \mathrm{O}\right)$ were found around the second cutting of the meadow at the end of July 2010 and amounted to 123.5 (33.4) $\mathrm{ng} \mathrm{m}^{-2} \mathrm{~s}^{-1}$. $\mathrm{CH}_{4}$ VMRs were the highest during snow cover and the lowest during periods of strong growth (Fig. 2). We attribute the sudden drop of $\mathrm{N}_{2} \mathrm{O}$ concentration values around the first cut in 2010 to a problem with the zero calibration of the QCL. Over the entire 2 years, the median VMR was $2.02(0.32) \mathrm{ppm}$ for $\mathrm{CH}_{4}$ $\left(\mathrm{N}_{2} \mathrm{O}\right)$, the median flux amounted to $9.6(0.9) \mathrm{ng} \mathrm{m}^{-2} \mathrm{~s}^{-1}$ (Fig. 2).

Daily average PAR was found between approx. $40 \mu \mathrm{mol} \mathrm{m} \mathrm{m}^{-2}$ in winter and $674 \mu \mathrm{mol} \mathrm{m}^{-2} \mathrm{~s}^{-1}$ in summer, with a median value of $215 \mu \mathrm{mol} \mathrm{m}{ }^{-2} \mathrm{~s}^{-1}$. In 2010, the yearly average $T_{\text {air }}$ at the field site of $6.1^{\circ} \mathrm{C}$ was colder than the long-term average (2001-2007) of $6.7^{\circ} \mathrm{C}$, while 2011 was warmer than average $\left(7.1^{\circ} \mathrm{C}\right)$. During this study, the maximum daily average $T_{\text {air }}$ was $22.7^{\circ} \mathrm{C}$ in July 2010 , the minimum of $-17.3^{\circ} \mathrm{C}$ was recorded in February 2012 (Fig. 2). $T_{\text {soil }}$ was similar in both years, approx. $8.5^{\circ} \mathrm{C}$ on average and values just above $0^{\circ} \mathrm{C}$ when snow covered the ground. SWC was the highest immediately after snow melt, with a maximum daily average value of $0.44 \mathrm{~m}^{3} \mathrm{~m}^{-3}$ at the end of February 2010, and the lowest in May 2011 after a period of only little precipitation $\left(0.08 \mathrm{~m}^{3} \mathrm{~m}^{-3}\right)$. In 2011, SWC was generally low $\left(0.25 \mathrm{~m}^{3} \mathrm{~m}^{-3}\right.$ averaged over the growing season) and significantly lower $(p<0.001)$ than in $2010\left(0.32 \mathrm{~m}^{3} \mathrm{~m}^{-3}\right)$. Over the duration of the flux measurements, precipitation was detected on 262 days, amounting to 525 and $537 \mathrm{~mm}$ in 2010 and 2011, respectively, and

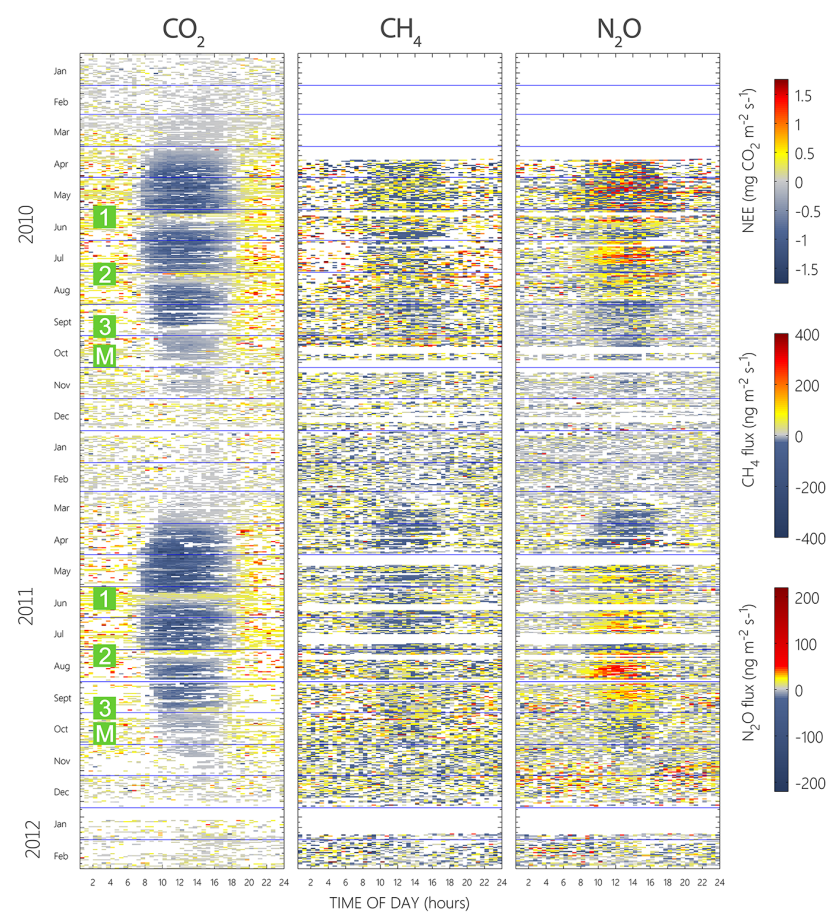

Figure 3. Half-hourly $\mathrm{CO}_{2}, \mathrm{CH}_{4}$ and $\mathrm{N}_{2} \mathrm{O}$ fluxes over 2 years of GHG flux measurements. The numbers 1, 2 and 3 in green squares indicate the first, second and third cutting of the meadow, respectively, while $M$ denotes manure spreading. Horizontal blue lines show the start and end of months. White color marks missing data.

$46 \mathrm{~mm}$ over the first 2 months in 2012 (Fig. 2). Relative air humidity (RHA) was around $80 \%$ on average over the whole measurement campaign, with minima below $50 \%$ in June 2010 (Fig. 2). In 2010 and 2011, the highest vapor pressure deficit (VPD) values of more than $1 \mathrm{kPa}$ were recorded during the warmer months between the end of May and August. GAI was below $1 \mathrm{~m}^{2} \mathrm{~m}^{-2}$ right after snow melt, reached maximum values of up to $8 \mathrm{~m}^{2} \mathrm{~m}^{-2}$ right before the first cut and was then reduced to below $1.5 \mathrm{~m}^{2} \mathrm{~m}^{-2}$ as a consequence of the cutting. GAI maxima before the second and third cut were lower compared to the first cut. Towards the end of the year after the third cut, GAI first increased and later decreased due to vegetation regrowth and senescence, respectively (Fig. 2).

The meadow was a source for $\mathrm{CO}_{2}$ during snow cover and became a net sink for $\mathrm{CO}_{2}$ some weeks after snowmelt and until the first cut (Fig. 3). The cutting event turned the meadow into a $\mathrm{CO}_{2}$ source for about 2 weeks before it again became a net sink. This behavior recurred after the second and third cut; however, the $\mathrm{CO}_{2}$ uptake after the last cutting was less pronounced than after the previous cuttings. More information about $\mathrm{CO}_{2}$ fluxes at the site was given by Wohlfahrt et al. (2008).

Fluxes of both $\mathrm{CH}_{4}$ and $\mathrm{N}_{2} \mathrm{O}$ showed high variability on a half-hourly timescale, especially during the first 2 

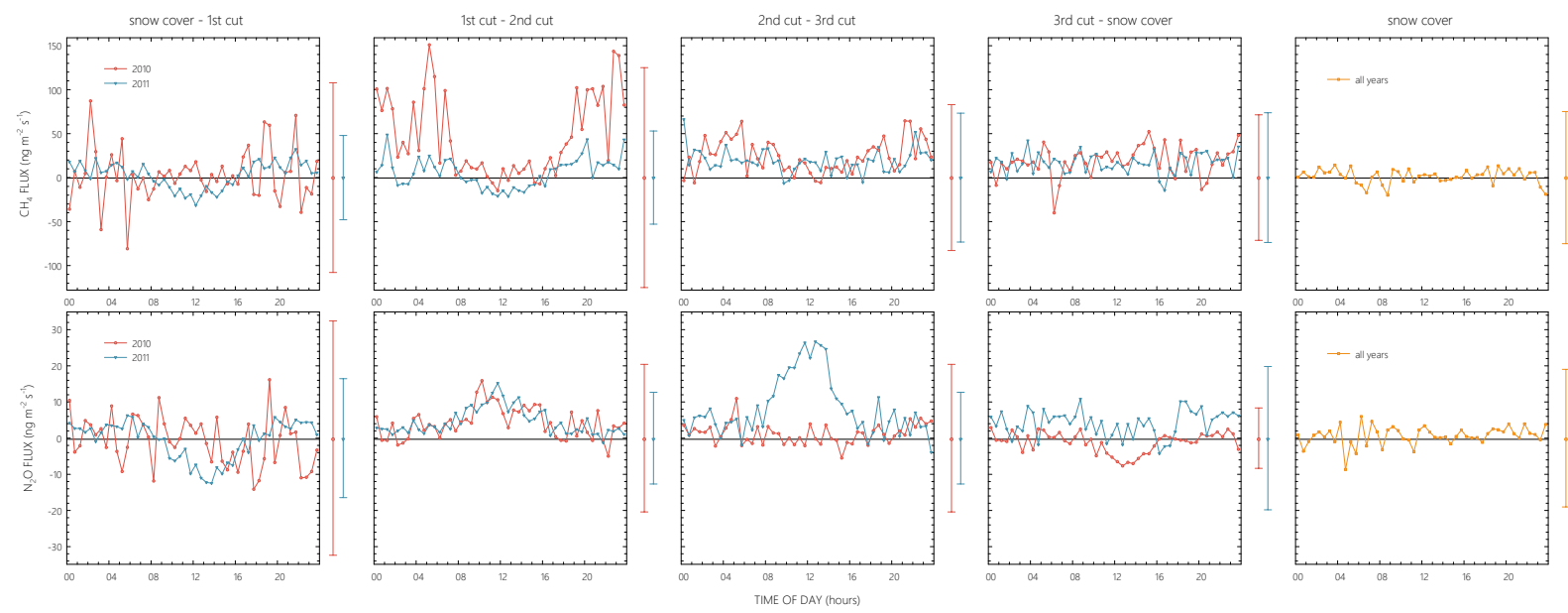

Figure 4. Diurnal cycles of $\mathrm{CH}_{4}$ and $\mathrm{N}_{2} \mathrm{O}$ fluxes during different time periods in 2010 and 2011. Whiskers to the right of each plot show the average standard deviation during the respective time period. Management data were excluded from the analysis.

months of the measurements and during the night (Fig. 3). However, $97 \%$ of all half-hourly $\mathrm{CH}_{4}$ and $\mathrm{N}_{2} \mathrm{O}$ fluxes during the vegetation period were found between \pm 200 and $\pm 50 \mathrm{ng} \mathrm{m}^{-2} \mathrm{~s}^{-1}$, respectively. During snow-free conditions and including only days not influenced by management events, the average $\mathrm{CH}_{4}$ and $\mathrm{N}_{2} \mathrm{O}$ flux was found at $14.0 \pm 80.7$ and $2.6 \pm 21.6 \mathrm{ng} \mathrm{m}^{-2} \mathrm{~s}^{-1}$, respectively (Fig. 3). Compared to these undisturbed conditions, average fluxes for both compounds were higher on days where the meadow was influenced by cutting events $(17.5 \pm 83.7$ and $4.8 \pm 20.7 \mathrm{ng} \mathrm{m}^{-2} \mathrm{~s}^{-1}$ ) and lower on days characterized by snow cover $(2.1 \pm 82.8$ and $0.9 \pm 20.7)$. The day of manure spreading, as well as the 2 days thereafter, was covered by our measurements only in October 2011. On the day of fertilization and 2 days later, average $\mathrm{N}_{2} \mathrm{O}$ fluxes were elevated $\left(3.5 \pm 17.2 \mathrm{ng} \mathrm{m}^{-2} \mathrm{~s}^{-1}\right)$ when compared to the rest of the same month (1.8 \pm 13.6$)$, while $\mathrm{CH}_{4}$ fluxes remained virtually unaffected $(24.7 \pm 91.0$ vs. $27.0 \pm 88.9)$. In total, emission fluxes were observed in 56 (57) \% of all recorded $\mathrm{CH}_{4}$ $\left(\mathrm{N}_{2} \mathrm{O}\right)$ half-hour periods (Fig. 3).

Average diurnal cycles of $F_{\mathrm{CH}_{4}}$ and $F_{\mathrm{N}_{2} \mathrm{O}}$ were often characterized by high variability with large fluctuations around zero, but followed a clear diurnal cycle during certain time periods (Fig. 4). Methane fluxes showed weak diurnal cycles after snowmelt and before the second cut in 2011, with peak average uptake rates of $-31.0 \pm 41.4 \mathrm{ng} \mathrm{m}^{-2} \mathrm{~s}^{-1}$ around noon. The uptake of $\mathrm{CH}_{4}$ before the first cut coincided with strong $\mathrm{N}_{2} \mathrm{O}$ deposition during daytime, with average peak rates of up to $-12.3 \pm 23.8 \mathrm{ng} \mathrm{m}^{-2} \mathrm{~s}^{-1}$ in the early afternoon. While $\mathrm{CH}_{4}$ fluxes continued to exhibit a very similar deposition pattern up until the second cut, $\mathrm{N}_{2} \mathrm{O}$ fluxes switched in sign and showed a clear diurnal cycle of constant emission during daytime, up to $15.4 \pm 18.9 \mathrm{ng} \mathrm{m}^{-2} \mathrm{~s}^{-1}$ on average just before noon. The $\mathrm{N}_{2} \mathrm{O}$ flux pattern after the first and before the second cut was very similar in both years, whereby peak emission rates in 2010 occurred earlier in the day (Fig. 4). In contrast to $\mathrm{CH}_{4}$ fluxes, which showed no clear diurnal pattern after the second cut in both years, the meadow constantly emitted $\mathrm{N}_{2} \mathrm{O}$ during daytime and before the third cut in 2011 , on average up to $26.8 \pm 23.3 \mathrm{ng} \mathrm{m}^{-2} \mathrm{~s}^{-1}$ around noon, while during daytime after the third cut in $2010 \mathrm{~N}_{2} \mathrm{O}$ was transported to the meadow, peak deposition amounted to $-7.5 \pm 8.8 \mathrm{ng} \mathrm{m}^{-2} \mathrm{~s}^{-1}$ on average. During snow cover, fluxes of both compounds fluctuated around zero (Fig. 4).

When all data were pooled, a MLR analysis explained 27 and $42 \%$ of the variability in daily average $\ln \left(F_{\mathrm{CH}_{4}}\right)$ and $\ln \left(F_{\mathrm{N}_{2} \mathrm{O}}\right)$, respectively, during snow-free conditions (Table 1). Over all years, the partial correlation (PC) of the net ecosystem exchange (NEE) of $\mathrm{CO}_{2}$ and $T_{\text {air }}$ with $\ln \left(F_{\mathrm{CH}_{4}}\right)$ was high and positive in sign, while SHF was negatively correlated with $\ln \left(\mathrm{CH}_{4}\right)$; all three PCs were highly significant $(p<0.001)$. During shorter time periods in-between, before and after cutting events in single years, the chosen set of parameters explained between 23 and $62 \%$ of the observed flux variability, with $r^{2}$ being highly significant only once, namely, in a period of high- $\mathrm{CH}_{4}$ uptake before the first cut in 2011, with NEE and $\mathrm{H}$ as the dominant regressors (Table 1). Explaining the $\ln \left(\mathrm{F}_{\mathrm{CH}_{4}}\right)$ variance during the same time periods but using data of both years worked best during the vegetation period until the second cut, and again after the third cut until snow cover, explaining up to $40 \%$ of observed ln transformed $\mathrm{CH}_{4}$ fluxes. The PC of SHF and NEE was significant during the early vegetation period and towards the end of the year, respectively. Latent heat flux (LE) was a significant regressor towards the end of the vegetation period and during snow cover (Table 1). We expanded on these findings by performing a forward stepwise MLR analysis using the same data, effectively reducing the number of variables in the regression equation but yielding similar results. In this analysis NEE, SHF, $T_{\text {air }}$ and VPD were identified as 
Table 1. Partial correlations of a multiple linear regression analysis and correlation coefficients $(r)$ of a simple linear regression analysis using daily average values of $\mathrm{ln}$ transformed $\mathrm{CH}_{4}\left(F_{\mathrm{CH}_{4}}\right)$ and $\mathrm{N}_{2} \mathrm{O}\left(F_{\mathrm{N}_{2} \mathrm{O}}\right)$ flux rates as dependent variables and air temperature $\left(T_{\text {air }}\right)$, soil temperature $\left(T_{\text {soil }}\right)$ and soil water content $(\mathrm{SWC})$ at $5 \mathrm{~cm}$ depth, soil heat flux $(\mathrm{SHF})$, net ecosystem $\mathrm{CO}_{2}$ exchange (NEE), latent heat flux (LE) and sensible heat flux (H), photosynthetically active radiation (PAR), vapor pressure deficit (VPD), relative air humidity (RHA) and $\mathrm{CH}_{4}\left(\mathrm{~N}_{2} \mathrm{O}\right)$ volume mixing ratios (VMRs) as independent variables. Management events were excluded from the analysis. Bold numbers highlight $p<0.05$, except bold underlined numbers resulted in $p<0.001$. Results shown for the vegetation period do not include time periods with snow cover on the meadow.

\begin{tabular}{|c|c|c|c|c|c|c|c|c|c|c|c|c|c|c|c|}
\hline & \multicolumn{14}{|c|}{ Multiple linear regression partial correlations } & \multirow{3}{*}{$\begin{array}{r}\begin{array}{r}\text { Simple linear } \\
\text { regression } r\end{array} \\
\begin{array}{r}\text { vegetation } \\
\text { period }\end{array} \\
2010-2011\end{array}$} \\
\hline & \multirow{2}{*}{$\begin{array}{r}\begin{array}{r}\text { vegetation } \\
\text { period }\end{array} \\
2010-11\end{array}$} & \multicolumn{3}{|c|}{ snow melt-first cut } & \multicolumn{3}{|c|}{ first cut-second cut } & \multicolumn{3}{|c|}{ second cut-third cut } & \multicolumn{3}{|c|}{ third cut-snow cover } & \multirow{2}{*}{$\begin{array}{l}\text { snow cover } \\
2010-2012\end{array}$} & \\
\hline & & 2010 & 2011 & $2010-2011$ & 2010 & 2011 & 2010-2011 & 2010 & 2011 & 2010-2011 & 2010 & 2011 & 2010-2011 & & \\
\hline \multicolumn{16}{|l|}{$\ln \left(F_{\mathrm{CH}_{4}}\right)$} \\
\hline$T_{\text {air }}$ & 0.19 & 0.07 & 0.07 & 0.25 & -0.02 & -0.35 & 0.11 & -0.05 & 0.32 & 0.02 & 0.20 & 0.01 & -0.02 & 0.17 & 0.13 \\
\hline$T_{\text {soil }}$ & $\overline{-0.04}$ & 0.10 & -0.07 & -0.16 & -0.13 & 0.57 & 0.10 & -0.08 & -0.12 & -0.09 & 0.01 & 0.15 & 0.11 & -0.11 & 0.16 \\
\hline SWC & 0.07 & 0.06 & -0.24 & 0.04 & -0.20 & -0.13 & 0.13 & 0.03 & 0.33 & 0.05 & 0.33 & -0.05 & -0.09 & -0.13 & 0.10 \\
\hline SHF & -0.22 & -0.14 & -0.14 & -0.26 & 0.12 & 0.22 & -0.16 & 0.02 & -0.28 & 0.01 & -0.29 & -0.08 & -0.10 & 0.04 & -0.09 \\
\hline NEE & $\underline{0.20}$ & 0.12 & 0.38 & 0.18 & 0.24 & 0.10 & 0.19 & -0.04 & 0.05 & 0.01 & 0.33 & 0.18 & 0.32 & 0.20 & $\underline{0.30}$ \\
\hline LE & $-\overline{0.05}$ & -0.16 & -0.17 & -0.12 & 0.09 & -0.23 & -0.05 & -0.21 & 0.10 & -0.17 & 0.20 & 0.48 & $\underline{0.44}$ & 0.28 & $\overline{-0.19}$ \\
\hline $\mathrm{H}$ & -0.06 & -0.08 & -0.38 & -0.13 & -0.25 & -0.03 & -0.09 & -0.08 & 0.13 & 0.10 & 0.01 & -0.33 & $-\overline{0.18}$ & -0.09 & $\overline{-0.19}$ \\
\hline PAR & 0.10 & 0.23 & 0.16 & 0.25 & -0.08 & -0.16 & 0.00 & 0.25 & -0.20 & 0.06 & -0.17 & -0.07 & -0.13 & 0.00 & $\overline{-0.19}$ \\
\hline VPD & -0.07 & 0.08 & 0.02 & -0.09 & -0.01 & 0.10 & -0.01 & 0.20 & -0.26 & 0.19 & -0.11 & -0.16 & -0.08 & -0.12 & $\overline{-0.09}$ \\
\hline RHA & 0.03 & 0.12 & 0.07 & 0.06 & 0.12 & 0.05 & 0.05 & 0.30 & -0.28 & 0.21 & -0.31 & 0.03 & 0.02 & -0.08 & $\underline{0.23}$ \\
\hline $\mathrm{CH}_{4} \mathrm{VMR}$ & 0.01 & 0.08 & 0.00 & 0.02 & 0.15 & 0.39 & 0.06 & -0.35 & 0.11 & -0.15 & 0.35 & -0.12 & -0.11 & 0.01 & $\overline{0.02}$ \\
\hline multiple $r^{2}$ & $\underline{0.27}$ & 0.31 & $\underline{0.54}$ & 0.20 & 0.43 & 0.62 & $\underline{0.36}$ & 0.41 & 0.23 & 0.18 & 0.55 & 0.53 & $\underline{0.40}$ & 0.22 & \\
\hline $\mathrm{N}$ & $\overline{356}$ & 47 & 67 & 114 & 50 & 36 & 86 & 44 & 40 & 84 & 35 & 37 & 72 & 82 & $365-397$ \\
\hline \multicolumn{16}{|l|}{$\ln \left(F_{N_{2}} \mathrm{O}\right)$} \\
\hline$T_{\text {air }}$ & 0.14 & -0.04 & 0.27 & 0.03 & 0.28 & -0.06 & 0.03 & 0.10 & 0.14 & 0.21 & 0.03 & 0.05 & 0.05 & 0.17 & $\underline{0.29}$ \\
\hline$T_{\text {soil }}$ & -0.11 & 0.09 & -0.16 & 0.06 & -0.16 & 0.22 & 0.30 & -0.07 & -0.06 & -0.27 & -0.22 & -0.18 & -0.33 & -0.12 & $\overline{0.24}$ \\
\hline SWC & -0.24 & -0.13 & -0.15 & -0.24 & -0.18 & -0.27 & -0.21 & -0.38 & -0.31 & -0.51 & 0.01 & -0.45 & -0.47 & -0.05 & $-\overline{0.33}$ \\
\hline SHF & $\overline{-0.02}$ & 0.03 & -0.23 & 0.02 & -0.26 & 0.16 & -0.11 & -0.12 & -0.11 & $\overline{-0.14}$ & 0.42 & 0.19 & 0.24 & -0.10 & 0.15 \\
\hline NEE & $\underline{0.23}$ & -0.16 & 0.31 & 0.13 & 0.10 & -0.10 & 0.10 & 0.35 & 0.24 & 0.32 & 0.32 & -0.12 & 0.09 & 0.02 & 0.00 \\
\hline LE & $\overline{0.19}$ & -0.16 & -0.11 & -0.08 & -0.10 & 0.07 & -0.03 & 0.04 & 0.19 & 0.11 & 0.41 & 0.05 & 0.17 & 0.18 & $\underline{0.22}$ \\
\hline $\mathrm{H}$ & $-\overline{0.14}$ & -0.24 & -0.16 & -0.23 & -0.08 & -0.20 & -0.14 & 0.45 & 0.00 & 0.18 & 0.22 & -0.10 & 0.13 & -0.25 & $-\overline{0.20}$ \\
\hline PAR & -0.02 & 0.21 & 0.21 & 0.13 & 0.37 & -0.03 & 0.22 & -0.22 & 0.18 & 0.02 & -0.37 & -0.04 & -0.32 & 0.06 & 0.05 \\
\hline VPD & 0.01 & -0.24 & -0.11 & -0.11 & 0.09 & -0.04 & 0.13 & 0.26 & 0.05 & 0.23 & -0.47 & -0.03 & -0.17 & -0.10 & 0.16 \\
\hline RHA & $\underline{0.24}$ & -0.21 & 0.18 & -0.01 & 0.45 & 0.03 & 0.33 & 0.37 & 0.23 & $\underline{0.37}$ & -0.60 & 0.07 & -0.13 & 0.00 & 0.08 \\
\hline $\mathrm{N}_{2} \mathrm{O}$ VMR & $\underline{0.25}$ & -0.05 & -0.11 & 0.02 & 0.39 & 0.28 & 0.26 & -0.15 & 0.11 & $-\overline{0.13}$ & -0.26 & -0.06 & -0.04 & $\underline{0.39}$ & $\underline{0.17}$ \\
\hline multiple $r^{2}$ & $\overline{0.42}$ & 0.19 & 0.55 & $\underline{0.26}$ & $\underline{0.76}$ & $\underline{0.73}$ & $\underline{0.66}$ & 0.72 & 0.56 & $\underline{0.68}$ & 0.73 & 0.68 & $\underline{0.73}$ & $\overline{0.44}$ & \\
\hline $\mathrm{N}$ & $\overline{360}$ & 49 & 67 & $\overline{116}$ & $\overline{50}$ & 36 & 86 & $\overline{44}$ & 41 & $\overline{85}$ & 36 & 37 & 73 & 83 & $369-401$ \\
\hline
\end{tabular}

the most significant regressors (all $p<0.05$ ), explaining $25 \%$ of the observed $\ln \left(\mathrm{F}_{\mathrm{CH}_{4}}\right)$ variability over all years excluding snow periods (data not shown). The SLR analysis found highly significant positive correlations for NEE and RHA, and highly significant negative correlations for LE, $\mathrm{H}$ and PAR (Table 1).

Generally, the MLR analysis resulted in $r^{2}$ being considerably higher for $\ln \left(F_{\mathrm{N}_{2} \mathrm{O}}\right)$ than for $\ln \left(F_{\mathrm{CH}_{4}}\right)$ (Table 1). The partial correlations were highly significant for multiple regressors. A positive PC was found for the ecosystem fluxes NEE and LE, and in addition for RHA, $T_{\text {air }}$ and $\mathrm{N}_{2} \mathrm{O}$ VMRs, while significant negative PCs were found for SWC, $\mathrm{H}$ and $T_{\text {soil }}$. All regressors combined were able to explain between 55 and $76 \%$ of the $\ln \left(F_{\mathrm{N}_{2} \mathrm{O}}\right)$ variance during shorter time periods in single years, with the exception of the time period before the first cut in 2010 when $r^{2}$ was found to be statistically not significant (Table 1). The chosen set of parameters performed well with pooled data during the same time periods and especially after the first cut, explaining between 66 and $73 \%$ of observed daily average $\ln \left(F_{\mathrm{N}_{2} \mathrm{O}}\right)$ values. SWC was the most dominant regressor towards the end of the year, featuring a highly significant, negative PC (Table 1). Similarly, $T_{\text {soil }}$ was an important parameter in the MLR analysis after the first cut, being first positively and then later negatively correlated with $\mathrm{ln}$ transformed $\mathrm{N}_{2} \mathrm{O}$ exchange. Seven parame- ters were highly significant $(p<0.001)$ in a forward stepwise MLR analysis and explained $41 \%$ of the $\ln \left(F_{\mathrm{N}_{2} \mathrm{O}}\right)$ variance during snow-free conditions, with $T_{\text {air }}, \mathrm{N}_{2} \mathrm{O}$ VMR, RH, NEE and LE being positively correlated, SWC and $\mathrm{H}$ negatively (data not shown). In a simple linear regression 8 out of 11 parameters were significantly correlated with the $\ln \left(F_{\mathrm{N}_{2} \mathrm{O}}\right)$, with $T_{\text {air }}$ and $T_{\text {soil }}$ as the highest positively and SWC as the highest negatively correlated regressors (Table 1).

A closer look at the two most prominent soil related re-

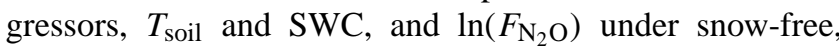
undisturbed conditions revealed a clear pattern. Daily average $\mathrm{N}_{2} \mathrm{O}$ exchange showed a bell-shaped relationship with SWC with the highest emissions during periods of intermediate soil water content (Fig. 5, top panel). Even clearer was the correlation between $T_{\text {soil }}$ and $\mathrm{N}_{2} \mathrm{O}$ flux: days with a daily average $T_{\text {soil }}$ above $14^{\circ} \mathrm{C}$ showed an almost consistent net emission of $\mathrm{N}_{2} \mathrm{O}$. This was also observed for days where $T_{\text {soil }}$ was close to $0^{\circ} \mathrm{C}$, whereas $\mathrm{N}_{2} \mathrm{O}$ exchange fluctuated around zero with no clear pattern between 0 and $14^{\circ} \mathrm{C}$ (Fig. 5, middle panel). Taking both SWC and $T_{\text {soil }}$ into account, days characterized by low to intermediate SWC with $T_{\text {soil }}$ close to $0^{\circ} \mathrm{C}$ or above $14^{\circ} \mathrm{C}$ generally resulted in a net emission of $\mathrm{N}_{2} \mathrm{O}$, while deposition was mainly observed during cool conditions with high SWC (Fig. 5, lower panel). In contrast 
Table 2. Daily average means in three different groups of daily net $\mathrm{CH}_{4}\left(\mathrm{~N}_{2} \mathrm{O}\right)$ exchange. Significant differences between group means were determined in a repeated measures ANOVA setting, using the unequal n HSD post hoc test. Group labels to the right of a given group mean show to which flux group the respective value was significantly different. Bold numbers mark group means that were significantly different from one other group, while bold underlined numbers denote group means that were significantly different from both other groups. $f+$ daily

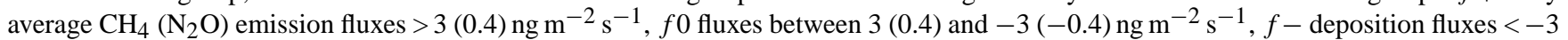
$(-0.4) \mathrm{ng} \mathrm{m}^{-2} \mathrm{~s}^{-1}$.

\begin{tabular}{|c|c|c|c|c|c|c|c|c|c|c|c|c|c|}
\hline \multirow{3}{*}{$\begin{array}{l}\text { Compound } \\
\text { flux class }\end{array}$} & \multicolumn{13}{|c|}{ Mean values, standard deviations and significant differences } \\
\hline & \multirow[b]{2}{*}{ Unit } & \multicolumn{5}{|c|}{$\mathrm{CH}_{4}$} & \multicolumn{7}{|c|}{$\mathrm{N}_{2} \mathrm{O}$} \\
\hline & & \multicolumn{2}{|l|}{$f+$} & \multicolumn{2}{|c|}{$f-$} & \multicolumn{2}{|c|}{$f 0$} & \multicolumn{2}{|c|}{$f+$} & \multicolumn{2}{|c|}{$f-$} & \multicolumn{2}{|c|}{$f 0$} \\
\hline$T_{\text {air }}$ & ${ }^{\circ} \mathrm{C}$ & $9.2 \pm 7.0$ & $f \mathbf{0}$ & $9.6 \pm 6.0$ & $f 0$ & $\underline{5.9 \pm 8.5}$ & $f+, f-$ & $10.1 \pm 7.5$ & fo & $8.4 \pm 5.1$ & fo & $\underline{4.2 \pm 7.3}$ & $f+, f-$ \\
\hline$T_{\text {soil }}$ & ${ }^{\circ} \mathrm{C}$ & $10.8 \pm 6.5$ & & $10.9 \pm 5.3$ & & $\overline{8.2 \pm 6.7}$ & & $11.5 \pm 6.8$ & $f \mathbf{0}$ & $10.1 \pm 4.8$ & f 0 & $\overline{6.5 \pm 5.5}$ & $f+, f-$ \\
\hline SWC & $\mathrm{m}^{3} \mathrm{~m}^{-3}$ & $0.29 \pm 0.06$ & & $0.28 \pm 0.06$ & & $0.29 \pm 0.09$ & & $\underline{0.27 \pm 0.07}$ & $f-, f 0$ & $0.31 \pm 0.05$ & $f+$ & $0 . \overline{32 \pm 0.06}$ & $f+$ \\
\hline SHF & $\mathrm{W} \mathrm{m}^{-2}$ & $1.0 \pm 6.9$ & $f-$ & $\underline{3.9 \pm 6.6}$ & $f+, f 0$ & $0.5 \pm 6.4$ & $f-$ & $2.2 \pm 7.3$ & $f 0$ & $1.4 \pm 6.0$ & & $-1.5 \pm 6.1$ & $f+$ \\
\hline NEE & $\mu \mathrm{g} \mathrm{CO}_{2} \mathrm{~m}^{-2} \mathrm{~s}^{-1}$ & $-70 \pm 224$ & $f-$ & $-220 \pm 229$ & $f+$ & $-119 \pm 220$ & & $-106 \pm 246$ & & $-141 \pm 220$ & & $-40 \pm 172$ & \\
\hline LE & $\mathrm{W} \mathrm{m}^{-2}$ & $55 \pm 53$ & $f-$ & $\underline{86 \pm 58}$ & $f+, f 0$ & $50 \pm 57$ & $f-$ & $67 \pm 64$ & fo & $64 \pm 44$ & $f 0$ & $\underline{30 \pm 37}$ & $f+, f-$ \\
\hline $\mathrm{H}$ & $\mathrm{W} \mathrm{m}^{-2}$ & $6.9 \pm 22.0$ & $f-$ & $20 . \overline{2 \pm 22.7}$ & $f+, f 0$ & $8.8 \pm 19.8$ & $f-$ & $7.5 \pm 22.8$ & $f-$ & $\underline{16.7 \pm 21.9}$ & $f+, f 0$ & $4 . \overline{4 \pm 16.8}$ & $f$ \\
\hline PAR & $\mu \mathrm{mol} \mathrm{m}{ }^{-2} \mathrm{~s}^{-1}$ & $271 \pm 158$ & $f-$ & $\overline{372 \pm 169}$ & $f+, f 0$ & $250 \pm 168$ & $f-$ & $293 \pm 180$ & & $\overline{314 \pm 149}$ & fo & $217 \pm 139$ & $f-$ \\
\hline VPD & $\mathrm{kPa}$ & $0.33 \pm 0.28$ & $f-$ & $\underline{0.42 \pm 0.26}$ & $f+, f 0$ & $0.28 \pm 0.29$ & $f-$ & $0.36 \pm 0.30$ & & $0.35 \pm 0.25$ & & $0.23 \pm 0.22$ & \\
\hline RHA & $\%$ & $81 \pm 10$ & $f-$ & $\underline{75 \pm 10}$ & $f+, f 0$ & $82 \pm 11$ & $f-$ & $81 \pm 10$ & $f-$ & $77 \pm 11$ & $f+$ & $82 \pm 12$ & \\
\hline VMR & $\mathrm{ppb}$ & $2014 \pm 59$ & & $20 \overline{04 \pm 53}$ & & $2021 \pm 60$ & & $319 \pm 6$ & $f-$ & $317 \pm 4$ & $f+$ & $319 \pm 4$ & \\
\hline $\mathrm{N}$ & days & 294 & & 96 & & 48 & & 261 & & 138 & & 44 & \\
\hline
\end{tabular}

to $\mathrm{N}_{2} \mathrm{O}$, comparably clear exchange patterns were not found for $\mathrm{CH}_{4}$ fluxes.

On a daily average timescale, a repeated measures ANOVA revealed statistically significant differences among environmental conditions on days with net uptake (group $f-$ ), net emission $(f+)$ or close-to-zero exchange ( $f 0)$ of $\mathrm{CH}_{4}$ and $\mathrm{N}_{2} \mathrm{O}$ (Table 2). In case of $\mathrm{CH}_{4}, T_{\text {air }}$ was significantly colder on low-flux days than on emission and deposition days. Generally, environmental conditions were most different between high-deposition days and days resulting in emission or close-to-zero exchange of $\mathrm{CH}_{4}$ (Table 2). In group $f-$, the ecosystem fluxes LE and H, SHF, PAR, VPD and RHA were all significantly higher compared to $f+$ and $f 0$, while also the net uptake of $\mathrm{CO}_{2}$ was larger. Although results were less clear for $\mathrm{N}_{2} \mathrm{O}$ fluxes, the meadow tended to act neither as a source or sink on days when air and soil temperatures as well as LE were low (Table 2). In addition, SWC was significantly lower in $f+$, while $\mathrm{H}$ was significantly higher on deposition days.

Cumulative fluxes for 2011 resulted in a net $\mathrm{CO}_{2}$ uptake of $-70.5 \mathrm{~g} \mathrm{CO}_{2} \mathrm{~m}^{-2}$ (Fig. 6). $\mathrm{CH}_{4}$ and $\mathrm{N}_{2} \mathrm{O}$ fluxes were converted to $\mathrm{CO}_{2}$ equivalents, with cumulative fluxes being calculated for each of the different FIR filter time constants. In 2011, the meadow acted as a source for both compounds. When no FIR filter was applied, i.e. the overestimation of the low-frequency eddy flux contribution was not corrected for, cumulative methane fluxes amounted to an emission of $54.5 \mathrm{~g} \mathrm{CO}_{2}$ equ. $\mathrm{m}^{-2}$. With FIR filters of varying time constants, cumulative fluxes were considerably lower, in the range of $6.8-19.3 \mathrm{~g} \mathrm{CO}_{2}$ equ. $\mathrm{m}^{-2}$, whereby the lower number was obtained using a FIR filter time constant of $50 \mathrm{~s}$ and constitutes our best guess estimate. Results were very similar for $\mathrm{N}_{2} \mathrm{O}$, the cumulative fluxes of which resulted in a net emission of $97.9 \mathrm{~g} \mathrm{CO}_{2}$ equ. $\mathrm{m}^{-2}$ without FIR filter, and 25.2-39.8 $\mathrm{g} \mathrm{CO}_{2}$ equ. $\mathrm{m}^{-2}$ using filters with different time constants. In case of $\mathrm{N}_{2} \mathrm{O}$, a time constant of $100 \mathrm{~s}$ was con- sidered to give the most representative flux results, yielding $32.0 \mathrm{~g} \mathrm{CO}_{2}$ equ. $\mathrm{m}^{-2}$ over the whole year (Fig. 6).

The total GHG budget can be calculated by summing up the different cumulative contributions of $\mathrm{CO}_{2}, \mathrm{CH}_{4}$ and $\mathrm{N}_{2} \mathrm{O}$. Based on the best guess estimates, the meadow acted as a GHG sink ( $-31.7 \mathrm{~g} \mathrm{CO}_{2}$ equ. $\mathrm{m}^{-2}$ ) in 2011. However, when no FIR filter was applied to neither $\mathrm{CH}_{4}$ nor $\mathrm{N}_{2} \mathrm{O}$ data, the sum of the two compound fluxes more than compensated for the sink effect of $\mathrm{CO}_{2}$, turning the meadow into a GHG source (81.9 g CO$_{2}$ equ. ${ }^{-2}$; Fig. 6).

\section{Discussion}

\subsection{Methane}

It was shown recently that plants do not contain a known biochemical pathway to synthesize methane (Nisbet et al., 2009), a finding that contradicts observations of methane emissions from terrestrial plants under aerobic conditions in an earlier study (Keppler et al., 2006). Methane emissions from plant tissue may be due to the transpiration of water that contains dissolved $\mathrm{CH}_{4}$ or due to the abiotic breakdown of plant material as a consequence of high-UV stress conditions (Nisbet et al., 2009), but the contribution of terrestrial plants to the global methane emission is considered to be small (Dueck et al., 2007). Based on these earlier findings it is feasible to regard observed eddy covariance emission fluxes in this study as a direct (methanogen microorganisms) or indirect (transpiration of soil $\mathrm{CH}_{4}$ ) consequence of processes in the soil, an important player in the global methane cycle (Kirschke et al., 2013; Smith et al., 2000).

Therefore, one might expect clear relationships between soil environmental parameters such as temperature or moisture and $\mathrm{CH}_{4}$ exchange, which were also reported by other studies (Dijkstra et al., 2013; Hartmann et al., 2010; Imer et 

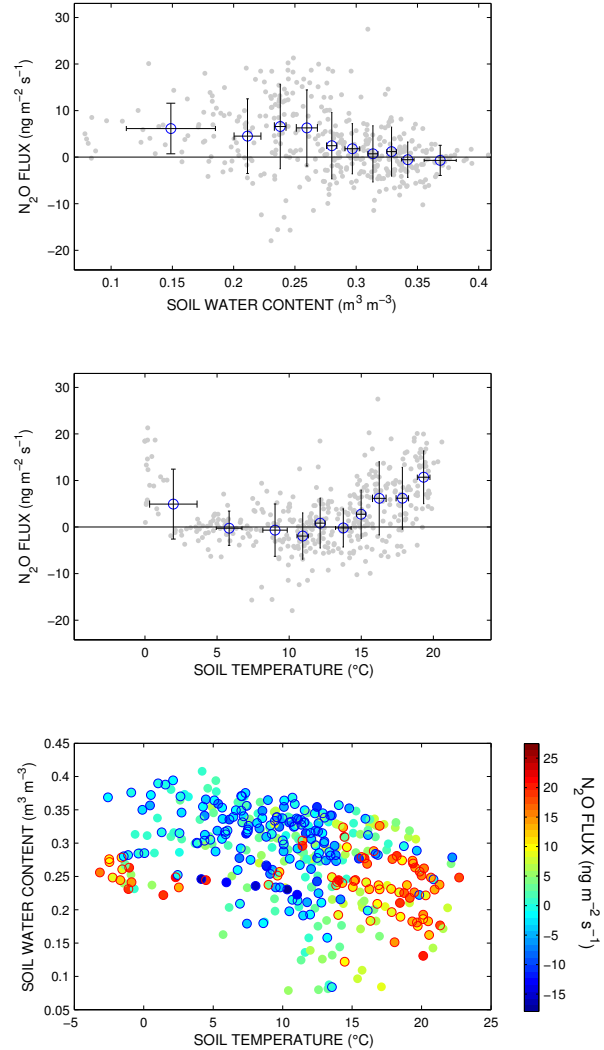

Figure 5. $\mathrm{N}_{2} \mathrm{O}$ daily average fluxes (grey dots) versus soil water content and soil temperature. Blue circles in the upper two panels show bin averages (40 days per bin), with error bars representing the standard deviation within each bin. In the lower panel, fluxes $<0 \mathrm{ng} \mathrm{m}^{-2} \mathrm{~s}^{-1}$ are circled in blue, fluxes $>9 \mathrm{ng} \mathrm{m}^{-2} \mathrm{~s}^{-1}$ are circled in red. Management events were excluded from the analysis.

al., 2013; Jackowicz-Korczyński et al., 2010; Kroon et al., 2010b; Liebig et al., 2009; Rinne et al., 2007; Schrier-Uijl et al., 2010). However, when all data were pooled no clear correlation between soil parameters and eddy covariance $\mathrm{CH}_{4}$ exchange at the grassland site in Neustift was observed. Although the explanatory power of $T_{\text {soil }}$ in the MLR was relatively high and significant between the first and second cutting of the meadow in 2011 - a period when small quantities of $\mathrm{CH}_{4}$ were taken up by the meadow around noon - no consistent relationship between soil parameters and the $\mathrm{CH}_{4}$ flux was observed (Table 1). SHF was significantly higher on days with net deposition compared to zero-flux and net emission days (Table 2), which might be an indication of soil processes as possible drivers for observed exchange patterns. The partial correlations of SWC with $\mathrm{CH}_{4}$ exchange, however, were statistically not significant throughout the measurement campaign and close to $0^{\circ} \mathrm{C}$ when all data were pooled (Table 1). This is in contrast to chamber studies that identified soil moisture as a key driver for methane exchange (e.g. Dijkstra et al., 2013).
One explanation for this lack of correlation between soil parameters and methane fluxes might be that half-hourly eddy covariance fluxes represent an integral signal, averaged over $30 \mathrm{~min}$ over a possibly heterogeneous area of methane sources and covering both hot spots of high-methane emissions and areas of relatively high uptake within the same flux footprint (Baldocchi et al., 2012). Therefore, SWC may be high in certain patches of the meadow and create environmental conditions conducive for methanogenic microorganisms, but low in other microsites across the grassland. Halfhourly fluxes reflect this heterogeneity across the footprint to a varying degree, mainly depending on wind direction, wind speed and atmospheric stability. In addition, the direct effect of certain drivers on $\mathrm{CH}_{4}$ exchange may smear out at ecosystem scale, especially if associated fluxes are generally low. Recently, Yvon-Durocher et al. (2014) found an average temperature dependence of $\mathrm{CH}_{4}$ emissions from aquatic, wetland and rice paddy ecosystems similar to that of $\mathrm{CH}_{4}$ production derived from pure cultures of methanogens and anaerobic microbial communities in the laboratory. No such relationship was found in the present study, which may be a direct consequence of a heterogeneous footprint with regards to $\mathrm{CH}_{4}$ sources and generally low $\mathrm{CH}_{4}$ fluxes at the measurement site in Neustift.

The observation of weak $\mathrm{CH}_{4}$ uptake around noon between March and July 2011 (Fig. 2) is most likely a consequence of methanotrophic microorganisms in the soil, a process enhanced by increased soil temperature. However, it is difficult to observe this temperature dependence at ecosystem scale, as the whole footprint regardless of emission/deposition hot spots is sampled. In addition, it was shown that both methanotrophic and methanogenic activity in the soil are temperature dependent (von Fischer and Hedin, 2007; Yavitt et al., 1995), whereby the latter tends to be more responsive to temperature (Topp and Pattey, 1997). Imer et al. (2013) reported nearly consistent methane uptake throughout the year except for winter at three different grassland sites along an altitudinal and management gradient using static chambers, with flux rates of generally below $10 \mathrm{ng} \mathrm{m}^{-2} \mathrm{~s}^{-1}$. Three pastures investigated by Liebig et al. (2009) were identified as minor $\mathrm{CH}_{4}$ sinks.

Daily average $\mathrm{CH}_{4}$ emissions in this study generally ranged up to $100 \mathrm{ng} \mathrm{m}^{-2} \mathrm{~s}^{-1}$ and were relatively similar to eddy covariance results over a drained and grazed peatland pasture during dry periods, when fluxes were often below $160 \mathrm{ng} \mathrm{m}^{-2} \mathrm{~s}^{-1}$ (Fig. 2; Baldocchi et al., 2012). However, the maximum $\mathrm{CH}_{4}$ flux and concentration of more than $5700 \mathrm{ng} \mathrm{m}^{-2} \mathrm{~s}^{-1}$ and $3500 \mathrm{ppb}$, respectively, at the peatland site were much higher than the $128 \mathrm{ng} \mathrm{m}^{-2} \mathrm{~s}^{-1}$ and $2300 \mathrm{ppb}$ recorded at Neustift. Higher maximum methane fluxes were also observed by Schrier-Uijl et al. (2010) over a grass ecosystem on peat $\left(1604 \mathrm{ng} \mathrm{m}^{-2} \mathrm{~s}^{-1}\right)$.

In comparison to $\mathrm{CO}_{2}$ and energy fluxes, there are only a few long-term EC methane exchange studies. However, year-round measurements are indispensable for accurately 


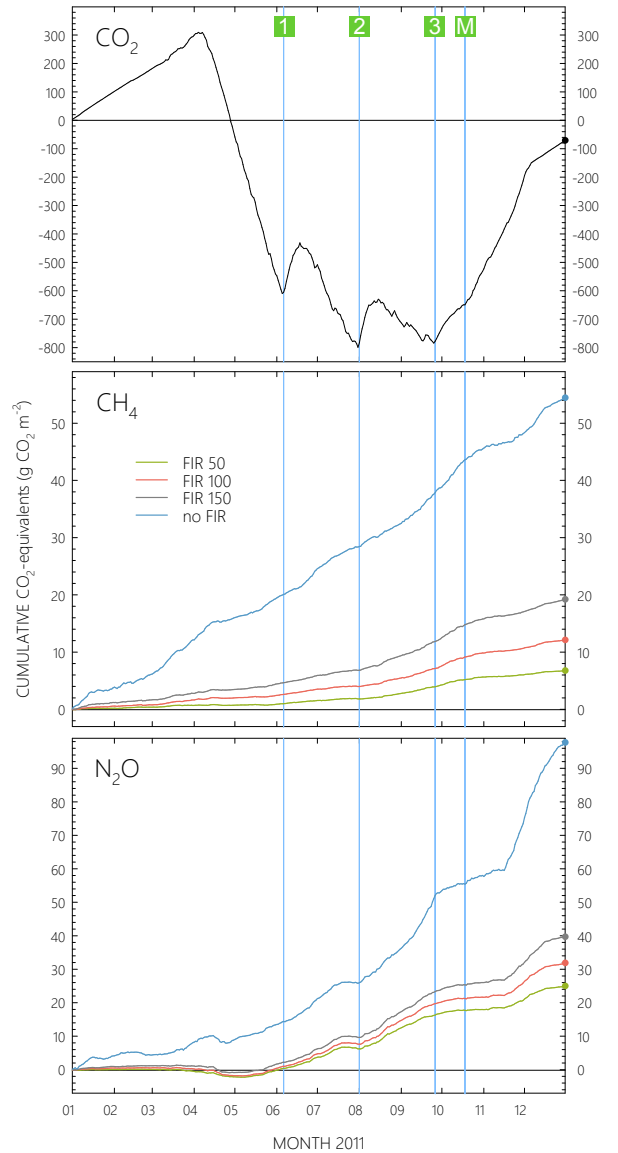

Figure 6. Cumulative GHG fluxes in 2011 expressed as $\mathrm{CO}_{2}$ equivalents. The effect of the finite impulse response (FIR) filter with different time constants is shown for $\mathrm{CH}_{4}$ and $\mathrm{N}_{2} \mathrm{O}$ budgets. Vertical lines show management dates, the numbers 1,2 and 3 in green squares indicate the first, second and third cutting of the meadow, respectively, while $M$ denotes manure spreading.

estimating the $\mathrm{CH}_{4}$ budget of an ecosystem. Baldocchi et al. (2012) reported a 3-year-mean annual methane efflux at a peatland pasture of $11.6 \pm 9.0 \mathrm{~g} \mathrm{~m}^{-2} \mathrm{yr}^{-1}$ without any discrimination for cattle or elongated footprints during the night, and $3.6 \pm 1.9 \mathrm{~g} \mathrm{~m}^{-2} \mathrm{yr}^{-1}$ when only daytime data representing the well-drained portion of the pasture, additionally filtered for favorable wind directions and the presence of cows, were used. This latter number is relatively similar to the methane efflux of $2.1 \mathrm{~g} \mathrm{~m}^{-2} \mathrm{yr}^{-1}$ in Neustift in 2011. In comparison, Hendriks et al. (2007) reported $14.2 \pm 26.1 \mathrm{~g} \mathrm{~m}^{-2} \mathrm{yr}^{-1}$ from the relatively dry portions of an abandoned peat meadow using chamber measurements, and $42.5 \pm 27.7 \mathrm{~g} \mathrm{~m}^{-2} \mathrm{yr}^{-1}$ when the whole meadow, including water-saturated land and ditches, was considered. Mander et al. (2010) conducted a literature survey and reported median fluxes of $0.16 \mathrm{~g} \mathrm{~m}^{-2} \mathrm{yr}^{-1}$ for fertilized grasslands on hydromorphic soils in Estonia, similar to Neustift $\left(0.27 \mathrm{~g} \mathrm{~m}^{-2} \mathrm{yr}^{-1}\right)$. Methane emissions reported by Merbold et al. (2014) from a grassland after restoration where 1 order of magnitude higher $\left(3.6 \mathrm{~g} \mathrm{~m}^{-2} \mathrm{yr}^{-1}\right)$. Using eddy covariance measurements, methane emissions between 24 and $29 \mathrm{~g} \mathrm{~m}^{-2} \mathrm{yr}^{-1}$ were reported from a subarctic peatland (Jackowicz-Korczyński et al., 2010), $12.6 \mathrm{~g} \mathrm{~m}^{-2} \mathrm{yr}^{-1}$ from a boreal fen (Rinne et al., 2007) and $16.5 \mathrm{~g} \mathrm{~m}^{-2} \mathrm{yr}^{-1}$ from a managed fen meadow (Kroon et al., 2010b).

Baldocchi et al. (2012) reported mean diurnal patterns characterized by the lowest methane efflux densities during midday and elevated methane emissions throughout the night, a pattern very similar to Neustift during certain time periods, e.g. between the first and second cut in 2010 (Fig. 4). We mainly attributed this observation to meteorological factors, i.e. intermittent exchange during calm and stable nighttime conditions, which was also the reasoning behind the outlier handling in our despiking procedure (Fig. 1a). Another reason might be the preferential sampling of an elevated methane source in combination with a larger nighttime footprint as described by Baldocchi et al. (2012). It is possible that methane emissions from a small stream and adjacent wet patches of the meadow, that are normally not part of the footprint, have contributed disproportionally to observed methane emissions. Unfortunately, we lack detailed highresolution spatial data (e.g. vegetation, soil) about small areas and patches within the sampled flux footprint in Neustift, which would be required for a meaningful footprint analysis. Therefore, we are currently not able to further discuss potential emission hotspots, their impact on calculated $\mathrm{CH}_{4}$ balances and the problem of possibly preferential sampling within this manuscript. Hot spot footprint analysis merits its own research and would provide important insights in how to interpret eddy covariance flux data.

Several studies reported that $81-90 \%$ of the total annual methane emissions occurred during the snow-free period or between spring and autumn (Jackowicz-Korczyński et al., 2010; Rinne et al., 2007), which is very similar to Neustift in 2011, where $84 \%$ of the yearly net $\mathrm{CH}_{4}$ emissions occurred during snow-free conditions.

\subsection{Nitrous oxide}

Despite occasional uptake, the meadow was a source of $\mathrm{N}_{2} \mathrm{O}$, in accordance with previous studies over managed grasslands. Half-hourly emission rates of $\mathrm{N}_{2} \mathrm{O}$, mostly below $50 \mathrm{ng} \mathrm{N}_{2} \mathrm{O} \mathrm{m}^{-2} \mathrm{~s}^{-1}$, were similar to exchange rates reported by Neftel et al. (2010) for an experimental farm site and Imer et al. (2013) from a mountain rangeland. $\mathrm{N}_{2} \mathrm{O}$ fluxes in 2011 amounted to an emission of $107 \mathrm{mg} \mathrm{m}^{-2} \mathrm{yr}^{-1}$. For comparison, Mander et al. (2010) reported approx. 94 and $723 \mathrm{mg} \mathrm{m}^{-2} \mathrm{yr}^{-1}$ for unfertilized and fertilized grasslands, respectively. Considerably higher emissions were found by Kroon et al. (2010b) for a managed fen meadow $\left(2.4 \mathrm{~g} \mathrm{~N}_{2} \mathrm{O} \mathrm{m}^{-2} \mathrm{yr}^{-1}\right)$, and by Merbold et al. (2014) for a grassland after restoration $\left(4.6 \mathrm{~g} \mathrm{~m}^{-2} \mathrm{yr}^{-1}\right)$. 
Many of the observations made for $\mathrm{CH}_{4}$ were also valid for $\mathrm{N}_{2} \mathrm{O}$, with generally low fluxes, a possibly heterogeneous flux footprint with respect to emission/deposition hot spots and soil processes as the driving force behind $\mathrm{N}_{2} \mathrm{O}$ exchange patterns. In contrast to $\mathrm{CH}_{4}$ exchange, $\mathrm{N}_{2} \mathrm{O}$ fluxes on a daily scale could be well explained by environmental parameters during specific time periods. The important role of temperature in soil processes was shown previously, as $\mathrm{N}$ mineralization, nitrification, denitrification and $\mathrm{N}_{2} \mathrm{O}$ emissions all increase with temperature (Barnard et al., 2005), while reduced soil moisture as a result of high air temperatures and increased plant transpiration can decrease $\mathrm{N}_{2} \mathrm{O}$ emissions ( $\mathrm{Li}$ et al., 1992). These findings are comparable to observations in the present study, where $\mathrm{N}_{2} \mathrm{O}$ exchange tended to emission during warm and relatively dry soil conditions (Fig. 5, lower panel).

$\mathrm{N}_{2} \mathrm{O}$ consumption in the soil occurs when $\mathrm{N}_{2} \mathrm{O}$ reduction exceeds $\mathrm{N}_{2} \mathrm{O}$ production (Chapuis-Lardy et al., 2007). Soil water is probably the key driver regulating $\mathrm{N}_{2} \mathrm{O}$ consumption in soils, as it can act as a temporary storage body that entraps $\mathrm{N}_{2} \mathrm{O}$, effectively hindering its diffusion from the soil matrix to the surface. As a consequence, the time for potential reduction of $\mathrm{N}_{2} \mathrm{O}$ to $\mathrm{N}_{2}$ through anaerobic denitrification is increased (Clough et al., 2005). This can result in a low $\mathrm{N}_{2} \mathrm{O} / \mathrm{N}_{2}$ ratio during wet conditions, which favors $\mathrm{N}_{2} \mathrm{O}$ consumption (Ruser et al., 2006; Wu et al., 2013). These observations agree with our findings at ecosystem scale. When all data were pooled, $\mathrm{N}_{2} \mathrm{O}$ uptake was the highest during relatively wet conditions (Fig. 5, top panel) and SWC was significantly lower on days with clear net emission of $\mathrm{N}_{2} \mathrm{O}$ (Table 2). The latter finding is further highlighted by a clear positive correlation between daily average $\ln \left(F_{\mathrm{N}_{2} \mathrm{O}}\right)$ and $T_{\text {soil }}$ in the soil temperature range $12-16^{\circ} \mathrm{C}$ as long as SWC was low (data not shown).

In October 2011, manure application resulted in a pulse of $\mathrm{N}_{2} \mathrm{O}$ emissions 1 day later, after which fluxes rapidly decreased and reached pre-fertilization rates 2 days after manure spreading. Similar behavior of $\mathrm{N}_{2} \mathrm{O}$ fluxes returning to background levels within 2-6 days after fertilization has been observed by Jones et al. (2011) for a Scottish grassland and Neftel et al. (2010) for an experimental farm site. Pulses of $\mathrm{N}_{2} \mathrm{O}$ emissions after fertilizer application were also described in other studies (e.g. Granli and Bockman, 1994; Jones et al., 2011) and might be the result of animal manure the most concentrated form of anthropogenic N input (Davidson, 2009) - directly fueling nitrifying and denitrifying bacteria in the soil, which are most active when $\mathrm{N}$ is abundant (Firestone and Davidson, 1989). Over the weeks following fertilization, $\mathrm{N}_{2} \mathrm{O}$ emissions increased with air temperature, which is in-line with the temperature dependence of the involved processes. We observed a sharp increase of $\mathrm{N}_{2} \mathrm{O}$ emissions once the daily average air temperature fell below the freezing point, approx. 4 weeks after manure spreading in November 2011. During this time period the meadow remained snow free, with soil temperatures close to $0^{\circ} \mathrm{C}$. The combination of reduced plant metabolism (low nitrate demand by plants) and prior manure spreading could result in an abundance of soil nitrate at the end of the vegetation period. Wertz et al. (2013) showed that denitrification can still occur at very low temperatures and even below the freezing point when nitrate and $\mathrm{C}$ are present. The observation of high- $\mathrm{N}_{2} \mathrm{O}$ emissions from frozen or nearly frozen soil was also made by earlier studies (Röver et al., 1998; Teepe et al., 2001).

Production and subsequent emission of $\mathrm{N}_{2} \mathrm{O}$ remained high after the beginning of the snow cover in December 2011. Zhu et al. (2005) described a similar situation where microbial activity in the soil of a lowland tundra did not cease during snow cover and $\mathrm{N}_{2} \mathrm{O}$ continuously diffused to the atmosphere through the snowpack. In Neustift, high $\mathrm{N}_{2} \mathrm{O}$ emissions were not observed 1 year earlier during similar conditions.

\subsection{Global warming potential}

The availability of year-round data allows for the calculation of a yearly GWP balance over a specific ecosystem. In this study, year-round $\mathrm{CH}_{4}, \mathrm{~N}_{2} \mathrm{O}$ and $\mathrm{CO}_{2}$ flux data were available for 2011. When expressing the net exchange of the three compounds in terms of $\mathrm{CO}_{2}$ equivalents and adding up these different contributions, the resulting GWP of the meadow in Neustift was $-32 \mathrm{~g} \mathrm{CO}_{2}$ equ. $\mathrm{m}^{-2} \mathrm{yr}^{-1}$ in 2011 , whereby a yearly NEE of $-71 \mathrm{~g} \mathrm{CO}_{2} \mathrm{~m}^{-2} \mathrm{yr}^{-1}$ was offset by $\mathrm{CH}_{4}$ and $\mathrm{N}_{2} \mathrm{O}$ emission of 7 and $32 \mathrm{~g} \mathrm{CO}_{2}$ equ. $\mathrm{m}^{-2} \mathrm{yr}^{-1}$, an offset of approx. $55 \%$.

Liebig et al. (2009) investigated 3 years of $\mathrm{CH}_{4}$ and $\mathrm{N}_{2} \mathrm{O}$ static chamber fluxes, soil organic carbon change, $\mathrm{CO}_{2}$ emissions associated with $\mathrm{N}$ fertilizer production and $\mathrm{CH}_{4}$ emissions from enteric fermentation for three grazing management systems. The resulting net GWP between -78 and $40 \mathrm{~g} \mathrm{CO}_{2}$ equ. $\mathrm{m}^{-2} \mathrm{yr}^{-1}$ is similar to results in this study. Hendriks et al. (2007) reported $-86 \mathrm{~g} \mathrm{CO}_{2}$ equ. $\mathrm{m}^{-2} \mathrm{yr}^{-1}$ from an abandoned peat meadow. Merbold et al. (2014) gave the full GHG flux budget of an intensively managed grassland after restoration, including ploughing. GHG emissions reported in their study were much higher than in Neustift, amounting to $2.9 \mathrm{kgCO}_{2}$ equ. $\mathrm{m}^{-2}$, and relatively similar to the balance of $1.6 \mathrm{~kg} \mathrm{CO}_{2}$ equ. $\mathrm{m}^{-2}$ found by Kroon et al. (2010b) for a managed fen meadow. Zona et al. (2013) reported a GHG balance of $-260 \mathrm{~g} \mathrm{CO}_{2}$ equ. $\mathrm{m}^{-2} \mathrm{yr}^{-1}$ for a poplar plantation in 2011, taking into account $\mathrm{CO}_{2}$ fluxes of $-351 \mathrm{~g} \mathrm{CO}_{2}$ equ. $\mathrm{m}^{-2} \mathrm{yr}^{-1}$, and $\mathrm{CH}_{4}$ and $\mathrm{N}_{2} \mathrm{O}$ fluxes of 49 and $42 \mathrm{~g} \mathrm{CO}_{2}$ equ. $\mathrm{m}^{-2} \mathrm{yr}^{-1}$, respectively, with $\mathrm{CH}_{4}$ and $\mathrm{N}_{2} \mathrm{O}$ offsetting the NEE sink by $26 \%$. Soussana et al. (2007) investigated the GHG budget of nine European grassland sites over 2 years, covering a major climatic gradient and a wide range of management regimes. On average, the investigated grassland plots were a net sink of $-879 \mathrm{~g} \mathrm{CO}_{2} \mathrm{~m}^{-2} \mathrm{yr}^{-1}$, and a net source of 117 and $51 \mathrm{~g} \mathrm{CO}_{2}$ equ. $\mathrm{m}^{-2} \mathrm{yr}^{-1}$ for $\mathrm{CH}_{4}$ and $\mathrm{N}_{2} \mathrm{O}$, respectively, with 
emissions of the latter two compounds resulting in a $19 \%$ offset of the NEE sink activity. Tian et al. (2014) reported offset ratios of $73 \%$ for the whole North American continent, with the grassland GWP being nearly neutral.

Rinne et al. (2007) reported a GWP balance of $+108 \mathrm{~g} \mathrm{CO}_{2}$ equ. $\mathrm{m}^{-2}$ when taking into account $\mathrm{CO}_{2}$ and $\mathrm{CH}_{4}$ fluxes from a boreal fen, with respective fluxes amounting to -156 and $+264 \mathrm{~g} \mathrm{CO}_{2}$ equ. $\mathrm{m}^{-2}$. Although the GWP calculated from $\mathrm{CO}_{2}$ and $\mathrm{CH}_{4}$ fluxes was much lower in Neustift $\left(-64 \mathrm{~g} \mathrm{CO}_{2}\right.$ equ. $\left.\mathrm{m}^{-2}\right)$, the situation was similar in that the carbon uptake of the meadow through $\mathrm{CO}_{2}$ was partially offset by carbon loss through $\mathrm{CH}_{4}$ emissions. The number for Neustift may change drastically on a year-toyear basis, as the meadow can act both as a source and sink of $\mathrm{CO}_{2}$ (Wohlfahrt et al., 2008), while it is supposedly a constant source of $\mathrm{CH}_{4}$. Dijkstra et al. (2013) used static chambers to calculate the GWP for 5 years of $\mathrm{CO}_{2}$ and $\mathrm{CH}_{4}$ data in a semiarid grassland, ranging between -3 and $-6 \mathrm{~g} \mathrm{CO}_{2}$ equ. $\mathrm{m}^{-2}$.

\section{Conclusions}

The grassland site in Neustift is characterized by low fluxes of $\mathrm{CH}_{4}$ and $\mathrm{N}_{2} \mathrm{O}$. Although the meadow can act as a source and sink for both compounds during certain time periods, it is a clear source of $\mathrm{CH}_{4}$ and $\mathrm{N}_{2} \mathrm{O}$ on an annual timescale. As a consequence, both gases contribute to an increase of the GWP, effectively reducing the sink strength in terms of $\mathrm{CO}_{2}$ equivalents.

Our analyses showed that daily average $\mathrm{N}_{2} \mathrm{O}$ exchange during most of the vegetation period can be well explained with simultaneously recorded ancillary data, especially in the time period after the first cut in June up until snow cover towards the end of the year. In contrast, modeling daily average exchange with the same ancillary data worked considerably worse for $\mathrm{CH}_{4}$, a finding that suggests the possibility of a more heterogeneous footprint in regard to methane sources and sinks. For both compounds it was not possible to single out one driving variable as the most important one, which is to be expected due to the nature of the eddy covariance flux signal in combination with generally low $\mathrm{CH}_{4}$ and $\mathrm{N}_{2} \mathrm{O}$ fluxes at the investigated grassland site.

In comparison to $\mathrm{CO}_{2}, \mathrm{H}_{2} \mathrm{O}$ and energy fluxes, the interpretation of $\mathrm{CH}_{4}$ and $\mathrm{N}_{2} \mathrm{O}$ exchange is challenging due to uncertainties regarding post-processing, quality control and footprint heterogeneity. Knowledge about emission and deposition hotspots within the footprint area would allow for a more comprehensive interpretation of the bulk EC flux. Additional information about GHG producing and consuming patches within the flux footprint could be achieved, for example, via chamber measurements; another possibility would be to perform a detailed statistical analysis of EC fluxes and underlying footprint information in combination with detailed spatial data of the sampled area.
We conclude that $\mathrm{CH}_{4}$ and $\mathrm{N}_{2} \mathrm{O}$ fluxes over supposedly well-aerated and moderately fertilized soils cannot be neglected when evaluating the GHG impact of temperate managed grasslands. Both compounds can significantly influence the GWP balance of a meadow and be determining if a grassland is acting as a source or sink of $\mathrm{CO}_{2}$ equivalents. In order to reliably assess GHG budgets on a local and global scale, long-term measurements of $\mathrm{CH}_{4}$ and $\mathrm{N}_{2} \mathrm{O}$ fluxes in combination with $\mathrm{CO}_{2}$ exchange are necessary, especially over ecosystems that are normally characterized by low GHG fluxes. In addition, we recommend to carefully check flux results and underlying co-spectra for an overestimation in the low-spectral range and correct for this effect if necessary.

Acknowledgements. This study was financially supported by the Austrian National Science Fund (FWF) under contract P23267B16, the Tyrolean Science Fund under contract Uni-404/1083 and the EU framework 7 project GHG Europe (EU contract no. 244122). Family Hofer (Neustift, Austria) is acknowledged for granting us access to the study site.

Edited by: P. Stoy

\section{References}

Allan, W., Struthers, H., and Lowe, D. C.: Methane carbon isotope effects caused by atomic chlorine in the marine boundary layer: Global model results compared with Southern Hemisphere measurements, J. Geophys. Res., 112, D04306, doi:10.1029/2006JD007369, 2007.

Baldocchi, D. D., Hincks, B. B., and Meyers, T. P.: Measuring Biosphere-Atmosphere Exchanges of Biologically Related Gases with Micrometeorological Methods, Ecology, 69, 1331, 1331-1340, doi:10.2307/1941631, 1988.

Baldocchi, D., Detto, M., Sonnentag, O., Verfaillie, J., Teh, Y. A., Silver, W., and Kelly, N. M.: The challenges of measuring methane fluxes and concentrations over a peatland pasture, Agric. For. Meteorol., 153, 177-187, doi:10.1016/j.agrformet.2011.04.013, 2012.

Bamberger, I., Hörtnagl, L., Schnitzhofer, R., Graus, M., Ruuskanen, T. M., Müller, M., Dunkl, J., Wohlfahrt, G., and Hansel, A.: BVOC fluxes above mountain grassland, Biogeosciences, 7, 1413-1424, doi:10.5194/bg-7-1413-2010, 2010.

Bamberger, I., Hörtnagl, L., Ruuskanen, T. M., Schnitzhofer, R., Müller, M., Graus, M., Karl, T., Wohlfahrt, G., and Hansel, A.: Deposition Fluxes of Terpenes over Grassland, J. Geophys. Res.Atmos., 116, D14305, doi:10.1029/2010JD015457, 2011.

Barnard, R., Leadley, P. W., and Hungate, B. A.: Global change, nitrification, and denitrification: A review, Global Biogeochem. Cy., 19, GB1007, doi:10.1029/2004GB002282, 2005.

Boucher, O., Friedlingstein, P., Collins, B., and Shine, K. P.: The indirect global warming potential and global temperature change potential due to methane oxidation, Environ. Res. Lett., 4, 044007, doi:10.1088/1748-9326/4/4/044007, 2009.

Bousquet, P., Ringeval, B., Pison, I., Dlugokencky, E. J., Brunke, E.G., Carouge, C., Chevallier, F., Fortems-Cheiney, A., Frankenberg, C., Hauglustaine, D. A., Krummel, P. B., Langenfelds, R. 
L., Ramonet, M., Schmidt, M., Steele, L. P., Szopa, S., Yver, C., Viovy, N., and Ciais, P.: Source attribution of the changes in atmospheric methane for 2006-2008, Atmos. Chem. Phys., 11, 3689-3700, doi:10.5194/acp-11-3689-2011, 2011.

Brilli, F., Hörtnagl, L., Hammerle, A., Haslwanter, A., Hansel, A., Loreto, F., and Wohlfahrt, G.: Leaf and ecosystem response to soil water availability in mountain grasslands, Agric. For. Meteorol., 151, 1731-1740, doi:10.1016/j.agrformet.2011.07.007, 2011.

Brilli, F., Hörtnagl, L., Bamberger, I., Schnitzhofer, R., Ruuskanen, T. M., Hansel, A., Loreto, F., and Wohlfahrt, G.: Qualitative and quantitative characterization of volatile organic compound emissions from cut grass, Environ. Sci. Technol., 46, 3859-65, doi:10.1021/es204025y, 2012.

Chapuis-Lardy, L., Wrage, N., Metay, A., Chotte, J.-L., and Bernoux, M.: Soils, a sink for $\mathrm{N}_{2} \mathrm{O}$ ? A review, Glob. Chang. Biol., 13, 1-17, doi:10.1111/j.1365-2486.2006.01280.x, 2007.

Cicerone, R. J. and Oremland, R. S.: Biogeochemical aspects of atmospheric methane, Global Biogeochem. Cy., 2, 299-327, doi:10.1029/GB002i004p00299, 1988.

Clough, T. J., Sherlock, R. R., and Rolston, D. E.: A Review of the Movement and Fate of $\mathrm{N}_{2} \mathrm{O}$ in the Subsoil, Nutr. Cycl. Agroecosystems, 72, 3-11, doi:10.1007/s10705-004-7349-z, 2005.

Collins, W. J., Sitch, S., and Boucher, O.: How vegetation impacts affect climate metrics for ozone precursors, J. Geophys. Res., 115, D23308, doi:10.1029/2010JD014187, 2010.

Crutzen, P. and Lelieveld, J.: Human Impacts on Atmospheric Chemistry, Annu. Rev. Earth Pl. Sci., 29, 17-45, doi:10.1146/annurev.earth.29.1.17, 2001.

Davidson, E.: The contribution of manure and fertilizer nitrogen to atmospheric nitrous oxide since 1860, Nat. Geosci., 2, 659-662, doi:10.1038/ngeo608, 2009.

Dijkstra, F. A., Morgan, J. A., Follett, R. F., and Lecain, D. R.: Climate change reduces the net sink of $\mathrm{CH}_{4}$ and $\mathrm{N}_{2} \mathrm{O}$ in a semiarid grassland., Glob. Chang. Biol., 19, 1816-26, doi:10.1111/gcb.12182, 2013.

Dlugokencky, E. J., Bruhwiler, L., White, J. W. C., Emmons, L. K., Novelli, P. C., Montzka, S. A., Masarie, K. A., Lang, P. M., Crotwell, A. M., Miller, J. B., and Gatti, L.V.: Observational constraints on recent increases in the atmospheric $\mathrm{CH}_{4}$ burden, Geophys. Res. Lett., 36, L18803, doi:10.1029/2009GL039780, 2009.

Dubbs, L. L. and Whalen, S. C.: Reduced net atmospheric $\mathrm{CH}_{4}$ consumption is a sustained response to elevated $\mathrm{CO}_{2}$ in a temperate forest, Biol. Fertil. Soils, 46, 597-606, doi:10.1007/s00374-0100467-7, 2010.

Dueck, T. A., de Visser, R., Poorter, H., Persijn, S., Gorissen, A., de Visser, W., Schapendonk, A., Verhagen, J., Snel, J., Harren, F. J. M., Ngai, A. K. Y., Verstappen, F., Bouwmeester, H., Voesenek, L. A. C. J., and van der Werf, A.: No evidence for substantial aerobic methane emission by terrestrial plants: a ${ }^{13}$ C-labelling approach., New Phytol., 175, 29-35, doi:10.1111/j.1469-8137.2007.02103.x, 2007.

Ehhalt, D. H. and Heidt, L. E.: Vertical profiles of $\mathrm{CH}_{4}$ in the troposphere and stratosphere, J. Geophys. Res., 78, 5265-5271, doi:10.1029/JC078i024p05265, 1973.

Firestone, M. and Davidson, E.: Microbiological basis of NO and $\mathrm{N}_{2} \mathrm{O}$ production and consumption in soil, in: Exchange of trace gases between terrestrial ecosystems and the atmosphere, edited by: Andreae, M. and Schimel, D., 7-21, Wiley., 1989.
Flechard, C. R., Neftel, A., Jocher, M., Ammann, C., and Fuhrer, J.: Bi-directional soil/atmosphere $\mathrm{N}_{2} \mathrm{O}$ exchange over two mown grassland systems with contrasting management practices, Glob. Chang. Biol., 11, 2114-2127, doi:10.1111/j.13652486.2005.01056.x, 2005.

Foken, T. and Wichura, B.: Tools for quality assessment of surfacebased flux measurements, Agric. For. Meteorol., 78, 83-105, doi:10.1016/0168-1923(95)02248-1, 1996.

Forster, P., Ramaswamy, V., Artaxo, P., Berntsen, T., Betts, R., Fahey, D. W., Haywood, J., Lean, J., Lowe, D.C., Myhre, G., Nganga, J., Prinn, R., Raga, G., Schulz, M., and Van Dorland, R.: Changes in Atmospheric Constituents and in Radiative Forcing, in: Climate Change 2007: The Physical Science Basis, Contribution of Working Group I to the Fourth Assessment Report of the Intergovernmental Panel on Climate Change, edited by: Solomon, S., Qin, D., Manning, M., Chen, Z., Marquis, M., Averyt, K. B.,Tignor, M., and Miller, H. L., Cambridge University Press, Cambridge, United Kingdom and New York, NY, USA, 129-234, 2007.

Fowler, D., Pilegaard, K., Sutton, M. A., Ambus, P., Raivonen, M., Duyzer, J., Simpson, D., Fagerli, H., Fuzzi, S., Schjoerring, J. K., Granier, C., Neftel, A., Isaksen, I. S. A., Laj, P., Maione, M., Monks, P. S., Burkhardt, J., Daemmgen, U., Neirynck, J., Personne, E., Wichink-Kruit, R., Butterbach-Bahl, K., Flechard, C., Tuovinen, J. P., Coyle, M., Gerosa, G., Loubet, B., Altimir, N., Gruenhage, L., Ammann, C., Cieslik, S., Paoletti, E., Mikkelsen, T. N., Ro-Poulsen, H., Cellier, P., Cape, J. N., Horváth, L., Loreto, F., Niinemets, Ü., Palmer, P. I., Rinne, J., Misztal, P., Nemitz, E., Nilsson, D., Pryor, S., Gallagher, M. W., Vesala, T., Skiba, U., Brüggemann, N., Zechmeister-Boltenstern, S., Williams, J., O’Dowd, C., Facchini, M. C., de Leeuw, G., Flossman, A., Chaumerliac, N., and Erisman, J. W.: Atmospheric composition change: Ecosystems-Atmosphere interactions, Atmos. Environ., 43, 5193-5267, doi:10.1016/j.atmosenv.2009.07.068, 2009.

Goldberg, S. D. and Gebauer, G.: Drought turns a Central European Norway spruce forest soil from an $\mathrm{N}_{2} \mathrm{O}$ source to a transient $\mathrm{N}_{2} \mathrm{O}$ sink, Glob. Chang. Biol., 15, 850-860, doi:10.1111/j.13652486.2008.01752.x, 2009a.

Goldberg, S. D. and Gebauer, G.: $\mathrm{N}_{2} \mathrm{O}$ and NO fluxes between a Norway spruce forest soil and atmosphere as affected by prolonged summer drought, Soil Biol. Biochem., 41, 1986-1995, doi:10.1016/j.soilbio.2009.07.001, 2009b.

Granli, T. and Bockman, O. C.: Nitrous oxide from agriculture, Norw. J. Agric. Sci. Suppl., 12, 1-128, 1994.

Hammerle, A., Haslwanter, A., Tappeiner, U., Cernusca, A., and Wohlfahrt, G.: Leaf area controls on energy partitioning of a temperate mountain grassland, Biogeosciences, 5, 421-431, doi:10.5194/bg-5-421-2008, 2008.

Hartmann, A. A., Buchmann, N., and Niklaus, P. A.: A study of soil methane sink regulation in two grasslands exposed to drought and $\mathrm{N}$ fertilization, Plant Soil, 342, 265-275, doi:10.1007/s11104-010-0690-x, 2010.

Hendriks, D. M. D., van Huissteden, J., Dolman, A. J., and van der Molen, M. K.: The full greenhouse gas balance of an abandoned peat meadow, Biogeosciences, 4, 411-424, doi:10.5194/bg-4411-2007, 2007.

Hörtnagl, L., Clement, R., Graus, M., Hammerle, A., Hansel, A., and Wohlfahrt, G.: Dealing with disjunct concentration 
measurements in eddy covariance applications: A comparison of available approaches, Atmos. Environ., 44, 2024-2032, doi:10.1016/j.atmosenv.2010.02.042, 2010.

Hörtnagl, L., Bamberger, I., Graus, M., Ruuskanen, T. M., Schnitzhofer, R., Müller, M., Hansel, A., and Wohlfahrt, G.: Biotic, abiotic, and management controls on methanol exchange above a temperate mountain grassland, J. Geophys. Res., 116, 1-15, doi:10.1029/2011JG001641, 2011.

Hörtnagl, L., Bamberger, I., Graus, M., Ruuskanen, T. M., Schnitzhofer, R., Walser, M., Unterberger, A., Hansel, A., and Wohlfahrt, G.: Acetaldehyde exchange above a managed temperate mountain grassland, Atmos. Chem. Phys., 14, 5369-5391, doi:10.5194/acp-14-5369-2014, 2014.

Holtan-Hartwig, L., Dörsch, P., and Bakken, L.R.: Low temperature control of soil denitrifying communities: kinetics of $\mathrm{N}_{2} \mathrm{O}$ production and reduction, Soil Biol. Biochem., 34, 1797-1806, 2002.

Hsieh, C.-I., Katul, G., and Chi, T.: An approximate analytical model for footprint estimation of scalar fluxes in thermally stratified atmospheric flows, Adv. Water Resour., 23, 765-772, doi:10.1016/S0309-1708(99)00042-1, 2000.

Imer, D., Merbold, L., Eugster, W., and Buchmann, N.: Temporal and spatial variations of soil $\mathrm{CO}_{2}, \mathrm{CH}_{4}$ and $\mathrm{N}_{2} \mathrm{O}$ fluxes at three differently managed grasslands, Biogeosciences, 10, 5931-5945, doi:10.5194/bg-10-5931-2013, 2013.

Ineson, P., Coward, P. A., and Hartwig, U. A.: Soil gas fluxes of $\mathrm{N}_{2} \mathrm{O}, \mathrm{CH}_{4}$ and $\mathrm{CO}_{2}$ beneath Lolium perenne under elevated $\mathrm{CO}_{2}$ ?: The Swiss free air carbon dioxide enrichment experiment, Plant Soil, 198, 89-95, 1998.

Jackowicz-Korczyński, M., Christensen, T. R., Bäckstrand, K., Crill, P., Friborg, T., Mastepanov, M., and Ström, L.: Annual cycle of methane emission from a subarctic peatland, J. Geophys. Res., 115, G02009, doi:10.1029/2008JG000913, 2010.

Jones, S. K., Famulari, D., Di Marco, C. F., Nemitz, E., Skiba, U. M., Rees, R. M., and Sutton, M. A.: Nitrous oxide emissions from managed grassland: a comparison of eddy covariance and static chamber measurements, Atmos. Meas. Tech., 4, 21792194, doi:10.5194/amt-4-2179-2011, 2011.

Karl, T. G., Spirig, C., Rinne, J., Stroud, C., Prevost, P., Greenberg, J., Fall, R., and Guenther, A.: Virtual disjunct eddy covariance measurements of organic compound fluxes from a subalpine forest using proton transfer reaction mass spectrometry, Atmos. Chem. Phys., 2, 279-291, doi:10.5194/acp-2-279-2002, 2002.

Keppler, F., Hamilton, J. T. G., Brass, M., and Röckmann, T.: Methane emissions from terrestrial plants under aerobic conditions, Nature, 439, 187-91, doi:10.1038/nature04420, 2006.

Khalil, M. A. K., Butenhoff, C. L., and Rasmussen, R. A.: Atmospheric methane: trends and cycles of sources and sinks, Environ. Sci. Technol., 41, 2131-7, 2007.

Kirschke, S., Bousquet, P., Ciais, P., Saunois, M., Canadell, J. G., Dlugokencky, E. J., Bergamaschi, P., Bergmann, D., Blake, D. R., Bruhwiler, L., Cameron-Smith, P., Castaldi, S., Chevallier, F., Feng, L., Fraser, A., Heimann, M., Hodson, E. L., Houweling, S., Josse, B., Fraser, P. J., Krummel, P. B., Lamarque, J.F., Langenfelds, R. L., Le Quéré, C., Naik, V., O’Doherty, S., Palmer, P. I., Pison, I., Plummer, D., Poulter, B., Prinn, R. G., Rigby, M., Ringeval, B., Santini, M., Schmidt, M., Shindell, D. T., Simpson, I. J., Spahni, R., Steele, L. P., Strode, S. A., Sudo, K., Szopa, S., van der Werf, G. R., Voulgarakis, A., van Weele,
M., Weiss, R. F., Williams, J. E. and Zeng, G.: Three decades of global methane sources and sinks, Nat. Geosci., 6, 813-823, doi:10.1038/ngeo1955, 2013.

Kroon, P. S., Hensen, A., Jonker, H. J. J., Zahniser, M. S., van 't Veen, W. H., and Vermeulen, A. T.: Suitability of quantum cascade laser spectroscopy for $\mathrm{CH}_{4}$ and $\mathrm{N}_{2} \mathrm{O}$ eddy covariance flux measurements, Biogeosciences, 4, 715-728, doi:10.5194/bg-4715-2007, 2007.

Kroon, P. S., Hensen, A., Jonker, H. J. J., Ouwersloot, H. G., Vermeulen, A. T., and Bosveld, F. C.: Uncertainties in eddy covariance flux measurements assessed from $\mathrm{CH}_{4}$ and $\mathrm{N}_{2} \mathrm{O}$ observations, Agric. For. Meteorol., 150, 806-816, doi:10.1016/j.agrformet.2009.08.008, 2010a.

Kroon, P. S., Schrier-Uijl, A. P., Hensen, A., Veenendaal, E. M., and Jonker, H. J. J.: Annual balances of $\mathrm{CH}_{4}$ and $\mathrm{N}_{2} \mathrm{O}$ from a managed fen meadow using eddy covariance flux measurements, Eur. J. Soil Sci., 61, 773-784, doi:10.1111/j.13652389.2010.01273.x, 2010b.

Kroon, P. S., Schuitmaker, A., Jonker, H. J. J., Tummers, M. J., Hensen, A., and Bosveld, F. C.: An evaluation by laser Doppler anemometry of the correction based on Kaimal cospectra for high frequency losses of EC flux measurements of $\mathrm{CH}_{4}$ and $\mathrm{N}_{2} \mathrm{O}$, Agric. Forest Meteorol, 150, 794-805, doi:10.1016/j.agrformet.2009.08.009, 2010c.

Li, C., Frolking, S., and Frolking, T. A.: A model of nitrous oxide evolution from soil driven by rainfall events: 2 . Model applications, J. Geophys. Res.-Atmos., 97, 9777-9783, doi:10.1029/92JD00510, 1992.

Liebig, M. A., Gross, J. R., Kronberg, S. L., Phillips, R. L., and Hanson, J. D.: Grazing management contributions to net global warming potential: a long-term evaluation in the Northern Great Plains., J. Environ. Qual., 39, 799-809, doi:10.2134/jeq2009.0272, 2009.

Mander, Ü., Uuemaa, E., Kull, A., Kanal, A., Maddison, M., Soosaar, K., Salm, J.-O., Lesta, M., Hansen, R., Kuller, R., Harding, A., and Augustin, J.: Assessment of methane and nitrous oxide fluxes in rural landscapes, Landsc. Urban Plan., 98, 172-181, doi:10.1016/j.landurbplan.2010.08.021, 2010.

Massman, W. J.: A simple method for estimating frequency response corrections for eddy covariance systems, Agric. For. Meteorol., 104, 247-251, doi:10.1016/S0168-1923(00)00164-7, 2000.

McMillen, R. T.: An eddy correlation technique with extended applicability to non-simple terrain, Boundary-Layer Meteorol., 43, 231-245, doi:10.1007/BF00128405, 1988.

Merbold, L., Eugster, W., Stieger, J., Zahniser, M., Nelson, D., and Buchmann, N.: Greenhouse gas budget $\left(\mathrm{CO}_{2}, \mathrm{CH}_{4}\right.$ and $\left.\mathrm{N}_{2} \mathrm{O}\right)$ of intensively managed grassland following restoration., Glob. Chang. Biol., 20, 1913-1928, doi:10.1111/gcb.12518, 2014.

Müller, M., Graus, M., Ruuskanen, T. M., Schnitzhofer, R., Bamberger, I., Kaser, L., Titzmann, T., Hörtnagl, L., Wohlfahrt, G., Karl, T., and Hansel, A.: First eddy covariance flux measurements by PTR-TOF, Atmos. Meas. Tech., 3, 387-395, doi:10.5194/amt-3-387-2010, 2010.

Neftel, A., Ammann, C., Fischer, C., Spirig, C., Conen, F., Emmenegger, L., Tuzson, B., and Wahlen, S.: $\mathrm{N}_{2} \mathrm{O}$ exchange over managed grassland: Application of a quantum cascade laser spectrometer for micrometeorological 
flux measurements, Agric. For. Meteorol., 150, 775-785, doi:10.1016/j.agrformet.2009.07.013, 2010.

Nisbet, E. G., Dlugokencky, E. J., and Bousquet, P.: Methane on the Rise - Again, Science, 343, 493-495, 2014.

Nisbet, R. E. R., Fisher, R., Nimmo, R. H., Bendall, D. S., Crill, P. M., Gallego-Sala, A. V., Hornibrook, E. R. C., LópezJuez, E., Lowry, D., Nisbet, P. B. R., Shuckburgh, E. F., Sriskantharajah, S., Howe, C. J., and Nisbet, E. G.: Emission of methane from plants., Proc. Biol. Sci., 276, 1347-54, doi:10.1098/rspb.2008.1731, 2009.

Peterjohn, W., Melillo, J., and Steudler, P.: Responses of trace gas fluxes and $\mathrm{N}$ availability to experimentally elevated soil temperatures, Ecol. Applications, 4, 617-625, 1994.

Phillips, R. L., Whalen, S. C., and Schlesinger, W. H.: Influence of atmospheric $\mathrm{CO}_{2}$ enrichment on methane consumption in a temperate forest soil, Glob. Chang. Biol., 7, 557-563, doi:10.1046/j.1354-1013.2001.00432.x, 2001.

Prather, M. J. and Hsu, J.: Coupling of nitrous oxide and methane by global atmospheric chemistry., Science, 330, 9524, doi:10.1126/science.1196285, 2010.

Prather, M. J., Holmes, C. D., and Hsu, J.: Reactive greenhouse gas scenarios: Systematic exploration of uncertainties and the role of atmospheric chemistry, Geophys. Res. Lett., 39, L09803, doi:10.1029/2012GL051440, 2012.

Revell, L. E., Bodeker, G. E., Smale, D., Lehmann, R., Huck, P. E., Williamson, B. E., Rozanov, E., and Struthers, H.: The effectiveness of $\mathrm{N}_{2} \mathrm{O}$ in depleting stratospheric ozone, Geophys. Res. Lett., 39, L15806, doi:10.1029/2012GL052143, 2012.

Rinne, J., Riutta, T., Pihlatie, M., and Aurela, M.: Annual cycle of methane emission from a boreal fen measured by the eddy covariance technique, Tellus B, 59, 449-457, doi:10.1111/j.16000889.2007.00261.x, 2007.

Röver, M., Heinemeyer, O., and Kaiser, E.-A.: Microbial induced nitrous oxide emissions from an arable soil during winter, Soil Biol. Biochem., 30, 1859-1865, doi:10.1016/S00380717(98)00080-7, 1998.

Ruser, R., Flessa, H., Russow, R., Schmidt, G., Buegger, F., and Munch, J. C.: Emission of $\mathrm{N}_{2} \mathrm{O}, \mathrm{N} 2$ and $\mathrm{CO}_{2}$ from soil fertilized with nitrate: effect of compaction, soil moisture and rewetting, Soil Biol. Biochem., 38, 263-274, doi:10.1016/j.soilbio.2005.05.005, 2006.

Ruuskanen, T. M., Müller, M., Schnitzhofer, R., Karl, T., Graus, M., Bamberger, I., Hörtnagl, L., Brilli, F., Wohlfahrt, G., and Hansel, A.: Eddy covariance VOC emission and deposition fluxes above grassland using PTR-TOF, Atmos. Chem. Phys., 11, 611-625, doi:10.5194/acp-11-611-2011, 2011.

Schlesinger, W. H.: An estimate of the global sink for nitrous oxide in soils., Glob. Chang. Biol., 19, 2929-2931, doi:10.1111/gcb.12239, 2013.

Schrier-Uijl, A. P., Kroon, P. S., Hensen, A., Leffelaar, P. A., Berendse, F., and Veenendaal, E. M.: Comparison of chamber and eddy covariance-based $\mathrm{CO}_{2}$ and $\mathrm{CH}_{4}$ emission estimates in a heterogeneous grass ecosystem on peat, Agric. For. Meteorol., 150, 825-831, doi:10.1016/j.agrformet.2009.11.007, 2010.

Schulze, E. D., Luyssaert, S., Ciais, P., Freibauer, A., Janssens et al., I. A., Soussana, J. F., Smith, P., Grace, J., Levin, I., Thiruchittampalam, B., Heimann, M., Dolman, A. J., Valentini, R., Bousquet, P., Peylin, P., Peters, W., Rödenbeck, C., Etiope, G., Vuichard, N., Wattenbach, M., Nabuurs, G. J., Poussi, Z., Nieschulze, J., and Gash, J. H.: Importance of methane and nitrous oxide for Europe's terrestrial greenhouse-gas balance, Nat. Geosci., 2, 842850, doi:10.1038/ngeo686, 2009.

Shindell, D. T., Faluvegi, G., Koch, D. M., Schmidt, G. A., Unger, N., and Bauer, S. E.: Improved attribution of climate forcing to emissions, Science, 326, 716-718, doi:10.1126/science.1174760, 2009.

Sjogersten, S. and Wookey, P. A.: Spatio-temporal variability and environmental controls of methane fluxes at the forest-tundra ecotone in the Fennoscandian mountains, Glob. Chang. Biol., 8, 885-894, doi:10.1046/j.1365-2486.2002.00522.x, 2002.

Smith, K. A., Dobbie, K. E., Ball, B. C., Bakken, L. R., Sitaula, B. K., Hansen, S., Brumme, R., Borken, W., Christensen, S., Priemé, A., Fowler, D., Macdonald, J. A., Skiba, U., Klemedtsson, L., Kasimir-Klemedtsson, A., Degórska, A., and Orlanski, P.: Oxidation of atmospheric methane in Northern European soils, comparison with other ecosystems, and uncertainties in the global terrestrial sink, Glob. Chang. Biol., 6, 791-803, doi:10.1046/j.1365-2486.2000.00356.x, 2000.

Soussana, J. F., Allard, V., Pilegaard, K., Ambus, P., Amman, C., Campbell, C., Ceschia, E., Clifton-Brown, J., Czobel, S., Domingues, R., Flechard, C., Fuhrer, J., Hensen, A., Horvath, L., Jones, M., Kasper, G., Martin, C., Nagy, Z., Neftel, A., Raschi, A., Baronti, S., Rees, R. M., Skiba, U., Stefani, P., Manca, G., Sutton, M., Tuba, Z., and Valentini, R.: Full accounting of the greenhouse gas $\left(\mathrm{CO}_{2}, \mathrm{~N}_{2} \mathrm{O}, \mathrm{CH}_{4}\right)$ budget of nine European grassland sites, Agric. Ecosyst. Environ., 121, 121-134, doi:10.1016/j.agee.2006.12.022, 2007.

Syakila, A. and Kroeze, C.: The global nitrous oxide budget revisited, Greenh, Gas Meas. Manag., 1, 17-26, doi:10.3763/ghgmm.2010.0007, 2011.

Syakila, A., Kroeze, C., and Slomp, C. P.: Neglecting sinks for $\mathrm{N}_{2} \mathrm{O}$ at the earth's surface: does it matter?, J. Integr. Environ. Sci., 7, 79-87, doi:10.1080/1943815X.2010.497492, 2010.

Teepe, R., Brumme, R., and Beese, F.: Nitrous oxide emissions from soil during freezing and thawing periods, Soil Biol. Biochem., 33, 1269-1275, doi:10.1016/S0038-0717(01)00084-0, 2001.

Tian, H., Chen, G., Lu, C., Xu, X., Hayes, D. J., Ren, W., Pan, S., Huntzinger, D. N., and Wofsy, S. C.: North American terrestrial $\mathrm{CO}_{2}$ uptake largely offset by $\mathrm{CH}_{4}$ and $\mathrm{N}_{2} \mathrm{O}$ emissions: toward a full accounting of the greenhouse gas budget, Clim. Change, 1-14, doi:10.1007/s10584-014-1072-9, 2014.

Topp, E. and Pattey, E.: Soils as sources and sinks for atmospheric methane, Can. J. Soil Sci., 77, 167-177, doi:10.4141/S96-107, 1997.

Vieten, B., Conen, F., Seth, B., and Alewell, C.: The fate of $\mathrm{N}_{2} \mathrm{O}$ consumed in soils, Biogeosciences, 5, 129-132, doi:10.5194/bg5-129-2008, 2008.

Von Fischer, J. C. and Hedin, L. O.: Controls on soil methane fluxes: Tests of biophysical mechanisms using stable isotope tracers, Global Biogeochem. Cy., 21, GB2007, doi:10.1029/2006GB002687, 2007.

Wertz, S., Goyer, C., Zebarth, B. J., Burton, D. L., Tatti, E., Chantigny, M. H., and Filion, M.: Effects of temperatures near the freezing point on $\mathrm{N}_{2} \mathrm{O}$ emissions, denitrification and on the abundance and structure of nitrifying and denitrifying soil communities., FEMS Microbiol. Ecol., 83, 242-54, doi:10.1111/j.1574-6941.2012.01468.x, 2013. 
Whalen, S. C.: Natural Wetlands and the Atmosphere, Env. Engineering Sc., 22, 73-94, 2005.

Wohlfahrt, G., Anfang, C., Bahn, M., Haslwanter, A., Newesely, C., Schmitt, M., Drosler, M., Pfadenhauer, J., and Cernusca, A.: Quantifying nighttime ecosystem respiration of a meadow using eddy covariance, chambers and modelling, Agric. For. Meteorol., 128, 141-162, doi:10.1016/j.agrformet.2004.11.003, 2005a.

Wohlfahrt, G., Bahn, M., Haslwanter, A., Newesely, C., and Cernusca, A.: Estimation of daytime ecosystem respiration to determine gross primary production of a mountain meadow, Agric. For. Meteorol., 130, 13-25, doi:10.1016/j.agrformet.2005.02.001, 2005b.

Wohlfahrt, G., Anderson-Dunn, M., Bahn, M., Balzarolo, M., Berninger, F., Campbell, C., Carrara, A., Cescatti, A., Christensen, T., Dore, S., Eugster, W., Friborg, T., Furger, M., Gianelle, D., Gimeno, C., Hargreaves, K., Hari, P., Haslwanter, A., Johansson, T., Marcolla, B., Milford, C., Nagy, Z., Nemitz, E., Rogiers, N., Sanz, M. J., Siegwolf, R. T. W., Susiluoto, S., Sutton, M., Tuba, Z., Ugolini, F., Valentini, R., Zorer, R., and Cernusca, A.: Biotic, Abiotic, and Management Controls on the Net Ecosystem $\mathrm{CO}_{2}$ Exchange of European Mountain Grassland Ecosystems, Ecosystems, 11, 1338-1351, doi:10.1007/s10021008-9196-2, 2008.

Wohlfahrt, G., Hammerle, A., Haslwanter, A., Bahn, M., Tappeiner, U., and Cernusca, A.: Seasonal and inter-annual variability of the net ecosystem $\mathrm{CO}_{2}$ exchange of a temperate mountain grassland: Effects of weather and management, J. Geophys. Res., 113, D08110, doi:10.1029/2007JD009286, 2008b.

Wu, D., Dong, W., Oenema, O., Wang, Y., Trebs, I., and Hu, C.: $\mathrm{N}_{2} \mathrm{O}$ consumption by low-nitrogen soil and its regulation by water and oxygen, Soil Biol. Biochem., 60, 165-172, doi:10.1016/j.soilbio.2013.01.028, 2013.
Xu-Ri and Prentice, I.: Terrestrial nitrogen cycle simulation with a dynamic global vegetation model, Glob. Chang. Biol., 14, 17451764, doi:10.1111/j.1365-2486.2008.01625.x, 2008.

Xu-Ri, Prentice, I. C., Spahni, R., and Niu, H. S.: Modelling terrestrial nitrous oxide emissions and implications for climate feedback., New Phytol., 196, 472-88, doi:10.1111/j.14698137.2012.04269.x, 2012.

Yavitt, J. B., Fahey, T. J., and Simmons, J. A.: Methane and Carbon Dioxide Dynamics in a Northern Hardwood Ecosystem, Soil Sci. Soc. Am. J., 59, 796-804, doi:10.2136/sssaj1995.03615995005900030023x, 1995.

Yvon-Durocher, G., Allen, A. P., Bastviken, D., Conrad, R., Gudasz, C., St-Pierre, A., Thanh-Duc, N., and del Giorgio, P. A.: Methane fluxes show consistent temperature dependence across microbial to ecosystem scales, Nature, 507, 488-491, doi:10.1038/nature13164, 2014.

Zhu, R., Sun, L., and Ding, W.: Nitrous oxide emissions from tundra soil and snowpack in the maritime Antarctic, Chemosphere, 59, 1667-75, doi:10.1016/j.chemosphere.2004.10.033, 2005.

Zona, D., Janssens, I. A., Aubinet, M., Gioli, B., Vicca, S., Fichot, R., and Ceulemans, R.: Fluxes of the greenhouse gases $\left(\mathrm{CO}_{2}\right.$, $\mathrm{CH}_{4}$ and $\mathrm{N}_{2} \mathrm{O}$ ) above a short-rotation poplar plantation after conversion from agricultural land, Agric. For. Meteorol., 169, 100110, doi:10.1016/j.agrformet.2012.10.008, 2013.

Zumft, W. G. and Kroneck, P. M. H.: Respiratory transformation of nitrous oxide $\left(\mathrm{N}_{2} \mathrm{O}\right)$ to dinitrogen by Bacteria and Archaea, Adv. Microb. Physiol., 52, 107-227, doi:10.1016/S00652911(06)52003-X, 2007. 